'THX: CELEBRATED ROMANCE OF THIB STIEALING OF THE MARE. TTRANSLATED FROM THE ORIGINAL ARABXC BY LADY ANNE BLUN'T. DONE INTO VERSE BY WILERTD SGAWEN BLUNI 
Webster Family : $\quad$ - cierınary Medicine

Cummings Schow. i Veterinary Medicine at

Tufts University

200 Westboro Road

North Grafton, MA 015\% 
THE STEALING OF THE MARE. 



\section{THE CELEBRATED ROMANCE OF}

THE STEALING OF THE MARE. TRANSLATED FROM THE ORIGINAL ARABIC BY LADY ANNE BLUNT. DONE INTO VERSE BY WILFRID SCAWEN BLUNT

LONDON: REEVES AND TURNER MDCCCXCII 
CHISWICK PRESS:-C. WHITTINGHAM AND CO., TOOKS COURT, CHANCERY LANE. 


\section{DEDICATION.}

TO

CHARLES DOUGHTY, ESQ,

IN RECOGNITION OF HIS KNOWLEDGE, THE MOST

COMPLETE AMONG ENGLISHMEN, OF

ARABIAN THINGS. 



\section{P R E F A C E.}

7 HE "Stealing of the Mare" is one of a cycle of tales forming the celebrated Mediæval "Ro1 mance of Abu Zeyd," which has remained popular in Egypt and North Africa for, it is affirmed, over 800 years. Of its author, as of Homer, nothing but his name, Abu Obeyd, is known. He is said to have lived in the third century of Islam, say the tenth of our era, a little after the events which the main portion of the Epic describes, and there is sufficient internal evidence to suggest that he was a native of Cairo, both in the Egyptian dialect used, and in the numerous allusions made to the Nile and to Egyptian customs and superstitions.

As an historic document the romance of Abu Zeyd would seem to be of no great value, hardly more than are the "Songs of Roland" and the "Morte d'Arthur" of contemporary Europe; that is to say, it rests on a thin basis of fact so overlaid with imaginative episodes, that the truth is impossible now to distinguish from the fiction. All that can be said to be historically certain is, that the Tribe of the Beni Helal, whose adventures it records, did through stress of famine migrate, about the end of the ninth or the beginning of the tenth century, from Central Arabia to Egypt; that it besieged and captured Belbeis, a frontier town of the Delta, and remained in the Eastern Egyptian desert for upwards of a generation, and that then it once again marched westvii 
ward to the conquest of Tunis, where it finally established itself, and where its descendants may still be found. The main fact of this march of the Beni Helal is at any rate a living event in Arab tradition. When crossing the Great Nefud of Northern Arabia in 1879, the translators of the present work had pointed out to them a track locally known as the Road of the Helalat; and further west, in $188 \mathrm{I}$, they found a similar tradition in regard to the group of hills lying between Gaza and Suez, and which has for its name the Jebel Helal. Moreover, the Howeytat Bedouins of Eastern Egypt, whose district adjoins Belbeis, have constantly affirmed to them their kinship with the historic tribe, though their claim is not admitted by other Bedouins, who give them a much less noble pedigree.

As a romance, "Abu Zeyd" is of more undoubted interest. It is not only an excellent example of the Mediæval Epic in its Eastern dress, but is old enough to have been itself, perhaps, a model from which Europe took its romantic inspiration. It is not generally remembered how immense an influence the Arab invasion of Spain in the eighth century had on European thought, political, religious, and literary. From Arabia through Spain the idea of Christian "chivalry" sprang, the romance of the horseman of noble blood armed with the lance as contrasted with the base-born citizen on foot. The knight-errantry of our middle-ages was purely Arabian; the championing of the distressed, especially of women, by wandering adventurers; the magviii 
nanimous code of honour in war; even the coats of mail-armour, and the heraldic bearings, which last may perhaps be traced to the "wusms" or family brands used in Arab tribes for the marking of their camels. Again, the feudalism of the middle ages was Arabian; the union of the temporal with the spiritual authority in politics; and in literature, the purely Semitic form of rhymed verse, as distinguished from the classic scansion and the unrhymed sagas of Europe. The romantic cycle of Abu Zeyd may very well have been known to the first singers of the cycle of Charlemagne and King Arthur, and have suggested to them their method.

Hardly less interesting is the picture given in the poem in question of Arab life and ideas, a picture naïve in its fidelity to the African form of Arabian thought. The hero, Salame Abu Zeyd, is the exact type of the North African Bedouin even of our own day, with his strange mixture of scepticism and superstition, of courage and cowardice, of truth and deceit, of romance and calculation. The particular episode of the "Stealing of the Mare" gives these last characteristics with peculiar vividness, and for that reason and for the liveliness of the plot and the individuality of the characters was chosen by the translators in preference to any other for a first attempt to introduce the poem to English notice.

It is strange that no translation of so remarkable an epic should have been hitherto made (so the present translators believe) into any European language. But the truth probably is that European scholars have been 
repelled from. such a work by the prejudices of native grammarians who affect to despise "Abu Zeyd" on account of the vulgar dialect in which it stands written. Whether such vulgarity was always its feature may be doubted. The matter of the poem is so good that it is difficult to believe that the form also was not originally a worthy one. It seems more probable that in the long history of its oral transmission through so many centuries the diction should have become corrupted than that it should have been from the beginning as irregular as we now find it. As it stands, with its local vulgarisms, and its uncertain and halting metre, it puzzles and repels the learned, and needs to be dealt with in an indulgent spirit, and with some knowledge of Bedouin customs and ways of thought, by whoever would give a fair idea of its merit in another tongue. It is in such a spirit that the present translation has been attempted. No liberty whatever has been taken with the matter of the narrative nor with its form, half prose, half verse, which has been strictly adhered to in all its alternations. Only the colloquialisms have been ignored, and for the metrical irregularities has been substituted a uniform metre as nearly as possible reproducing to the English ear the rhythm of the less imperfect portions of the poem. In reading it, it must be remembered that the original is not, strictly speaking, a written poem with an authentic text, though a version of it in Arabic has in recent years been printed; but that it is still what the Iliad and Odyssey probably were for many centuries, an unwritten epic 
orally transmitted from one generation to another of unlettered reciters. Lane, in his " Modern Egyptians," notices it in this sense, and gives a few specimen lines in translation, though, as it seems to the present translators, not too happily. The original metre, indeed, defies any quite close rendering into English, as it continues throughout on a single irregular rhyme or assonance beyond the scope of the richest of European languages to reproduce. The double ending adopted in the present translation its writers think is the nearest imitation possible in English of the original cadence. Listened to in an Arab tent, or in the reception room of an Egyptian country Sheykh, when the wandering poet is reciting it to an intelligent audience who knows it well, and who waits the close of each line to repeat after him the final syllable, it has a noble rhythmical effect and is very impressive. Let the English reader imagine this when he is perusing the present pages, and he will appreciate better the nature of this ancient Arabian poem as it sounds to Arabian ears, and will not, the translators hope, turn from it wholly disappointed. 



\section{THE STEALING OF THE MARE.}

TN the name of God the Merciful, the Compassionate!

He who narrateth this tale is $A$ ви OвEYD, and 1 he saith:

When I took note and perceived that the souls of men were in pleasure to hear good stories, and that their ears were comforted and that they made good cheer in the listening, then called I to mind the tale of the Agheyli Jaber and his mare, and of all that befell him and his people. For this is a story of wonderful adventure and marvellous stratagems, and a tale which when one heareth he desireth to have it evermore in remembrance as a delight tasted once by him and not forgotten.

And the telling of it is this :

The Emir Abu Zeyd the Helali Salame was sitting one morning in his tent with the Arabs of the Beni Helal and the Lords of the tribe. And lo, there appeared before them in the desert the figure of one wandering to and fro alone. And this was Ghanimeh. And the Emir Abu Zeyd said to his slave Abul Komsan, "Go forth thou, and read me the errand of this fair Lady and bring me word again." And Abul Komsan went forth as he was bidden, and presently returned to them with a smiling countenance, and he said, " $\mathrm{O}$ my Lord, there is the best of news for thee, for this is one that hath come a guest to thee, and she desireth something of thee, for fate hath oppressed her and troubles sore are on her head. And she hath told me all her story and the reason 
of her coming, and that it is from her great sorrow of mind; for she had once an husband, and his name was Dagher abul Jud, a great one of the Arabs. And to them was born a son named Ameribn el Keram, and the boy's uncle's name was En Naaman. And when the father died, then the uncle possessed himself of all the inheritance, and he drove forth the widow from the tribe; and he hath kept the boy as a herder of his camels; and this for seven years. And Ghanimeh all that time was in longing for her son. But at the end of the seventh year she returned to seek the boy. Then Naaman struck her and drove her forth. And Amer, too, the boy, his nephew, is in trouble, for Naaman will not now yield to the boy that he should marry his daughter, though she was promised to him, and he hath betrothed her to another. And when Amer begged him for the girl (for the great ones of the tribe pitied the boy, and there had interceded for him fifty-and-five of the princes,) he answered, 'Nay, that may not be, not though in denying it I should taste of the cup of evil things. But, if he be truly desirous of the girl and would share all things with me in my good fortune, then let him bring me the mare of the Agheyli Jaber,-and the warriors be witness of my word thereto.' But when the men of the tribe heard this talk, they said to one another: 'There is none able to do this thing but only Abu Zeyd.' And thus hath this lady come to thee. And I entreat thee, my lord, look into her business and do for her what is needful." 
And when Abu Zeyd heard this word of his slave Abul Komsan he rejoiced exceedingly, and his heart waxed big within him, and he threw his cloak as a gift to Abul Komsan, and he bade him go to the Lady, Ghanimeh and treat her with all honour, for, "I needs," said he, "must see to her affairs and quiet her mind." So Abul Komsan returned to her, and he built for her a tent, and did all that was needed. And Abu Zeyd bade him attend upon her and bring her dresses of honour and all things meet for her service.

Then began the narrator to sing :

Saith the hero Abu Zeyd the Helali Salame :

(Woe is me, my heart is a fire, a fire that burneth!),

On a Friday morning once, I sat with three companions, I in my tent, the fourth of four, with the sons of Amer. Sudden I raised my eyes and gazed at the breadth of the desert,

Searching the void afar, the empty hills and the valleys;

Lo in the midmost waste a form, where the rainways sundered,

Wandering uncertain round in doubt, with steps of a stranger.

Turned I to Abul Komsan, my slave, and straightway I bade him,

"Ho, thou master of signs, expound to us this new comer."

Abul Komsan arose and went, and anon returning, 
"Fortune fair," said he, "I bring and a noble token. "O my Lord Abu Zeyd," he cried, and his lips were smiling,

"Here is a guest of renown for thee, a stranger, a lady, One for the wounding of hearts, a dame of illustrious lineage,

One whose heart is on fire with grief, and sorely afflicted." The dark one threw off his cloak to Abul Komsan in guerdon,

Even I, Abu Zeyd Salame, the while my companions Rose with me all as I rose in my place, we four rejoicing, Hassan and Abu Kheyl Diab, and the Kadi Faid. And first of them Hassan spake and said, "Is my name not Hassan?

Sultan and chief and lord am I of the lords of the Bedu. Shall not my tent stand free to all, to each guest that cometh?

So God send her to me, be they hers, two thousand camels." And Abu Kheyl uprose, and with him the Kadi Faid. "And I," said he, "no less will give to this dame two thousand."

Nor was the Kadi slow to speak: "Though this pen and paper

All my poor fortune be," said he, "I will name her thirty."

But I, Salame, said, "By my faith, these gifts were little; Mine be a larger vow." And I swore an oath and I promised

All that she would to bring, nay, all her soul demanded, 
Even a service of fear, a thing from the land of danger. And thus they sat in discourse till the hour of noon was upon them,

And the caller called to prayer, and the great ones prayed assembled;

And these too in their place, and they stood in prayer together.

And when they had made an end of praises and prostrations,

Back to the tent came they, and still behold the lady Wandering in doubt uncertain there with steps of a stranger.

Then to the desert went I forth, and I called and I shouted,

"Marhaba, welcome to thee," I cried, "thou illustrious lady,

Welcomes as many be to thee as the leagues thou hast wandered."

And she, "I seek the hero, the Knight of Helal ibn Amer, Bring me to him, the renowned of might, the hero of Amer."

And I, "I hear and obey, though I am not of the great ones.

Raise thy eyes and behold him here, the Sultan Hassan, And with him Abu Musa Diab, the light of Zoghbat, Best of the swordsmen he, and our learned Kadi Faid, The reader of the word, the learnedest of the learned, And with them Aziz ed Din and El Hajin and Amer, Fifty and five of the best, Fulano and Fulano. 
These be men of their word; asking thou shalt obtain it : Ask thou all that thou wilt, even all thy soul desireth." But she, "Nay, thou dost mock, thou slave and idle talker,

Not of these would I hear nor of other than Salame, Salame Abu Zeyd, Chief of Helal ibn Amer.

Why art thou mute of him for whom my soul is enkindled?"

And I, "Myself am he, the Helali Salame,

Welcome to thee, and welcome as wide as thou hast wandered."

And she prayed, "O Abu Zeyd, behold me here thy stranger.

A boon I ask, $\mathrm{O}$ dark one, a mighty deed of daring. Thy suppliant am I, thou son of Risk Salame, From the distress of time behold my tears are flowing. For this one boon behold me pleading here before thee. I have tasted Fortune's change. I plead by the day of judgment."

And I, "What is thy want, O Lady, that I grant itAll, to the cord, I give, so thy tears cease from flowing." And she, "O man admired! A great one was my husband,

A knight, a prince of lineage, Abul Jud Dagher, A man of mighty wealth, stored up in many houses, Wealth whose sole catalogue were a library of volumes. He dying left behind with me our one son Amer; To me and to the hate of an ill-minded uncleFor when that Abul Jud was gathered to his fathers, 
And sent from his loved home to death's unjoyful dwellings,

Behold this Naaman, this man he called his brother, In arms against our house, he with his evildoers, Raiding all our wealth and making Amer captive. Thus weeping did I flee, and seven long years an exile Bore I his heart with me like a bird ever flying. And then, the seven years done, to the dear place forbidden

Turned I in my love and my sweet son's remembrance. And when he saw me near he called to me, ' $O$ mother, Behold me in what straits I lie through men of evil(And these may God requite!)-Seven years behold me outcast,

Herding the flocks afar each day in the lone desert, And in my uncle's tent nightly a guest unwelcome. Yet was there one with me, his daughter fair, Betina, Whom I, as of little count, might wander with unquestioned

Until but few days since. But now another suitor Asking her hand hath come, and with him brave companions.

And for this suitor's sake am I forbid her presence. And what then, O my mother, shall I do, my mother, Who have neither riches, though my soul is generous, Nor wile nor stratagem in my life's little wisdom? How shall I win to her this fair child of my uncle? How shall I answer her, her greetings night and morning?' 
Thus spake he, and I heard, and with a heart of anger

Went I forth with him my son, and to the tribesmen Pleaded in every tent his cause, we two as suppliants, Calling on all their chiefs to give the hand of succour. And fifty and five of them were those who lent agreement,

This one and that with joy, Fulano and Fulano. And with them Selman was, Abul Jud el Aser. And Jafferi was there, Khalifa ibn Nasser, And many more of note. And they rose and went assembled

To the council of the king, and found him there in judgment

Set with his valiant men, and meting out obedience. And when En Naaman saw them he cried to them in welcome :

'Sit ye, O chiefs, with me,' and made their place beside him.

And when he found them mute and of their manner bashful,

'Ye have come,' said he, 'to speak of him, my brother's orphan.'

And they, 'Ay, of a truth. We ask for him Betina.' And he, 'Be short of words. From me ye shall get no lying.

Nasser hath come for her, and with him a brave dowry. This one, what hath he-speak-beside his beggar's portion?' 
And they, 'But we will give. So be thy mind unburdened,

And his, too, of the doubt. We stand to thee his guarants.'

And Selman spake, 'Behold it, to the last coin, his dowry.'

And Jafferi, ' Nor less, things needed for the wedding. All that thou wilt we bring, a gift to thee and Amer.'

Then answered them the hero, En Naaman, the chieftain :

' List to my word, $\mathrm{O}$ chiefs, $\mathrm{O}$ generous-minded princes. Let him but bring one thing, the thing my soul desireth,

So shall I stand content, nor ask a further dowry,

Necklace, nor chain, nor ring, nor ornament of silver,

Nor silk, nor broidered robe, and, lo, my word is on it. He shall be to me a son, and I will love him truly,

More than a brother's son, in all things first and foremost.

But come he empty-handed, the girl shall be another's.' And so with a pious phrase the hero left them wondering.

And straightway questioned all, 'And what is this, $\mathrm{O}$ Naaman?'

Laughing he made reply, "The mare of Agheyli Jaber.'

Then on the chiefs assembled there fell as it were a tremour,

And each man looked at each, nor made they further pleading, 
Only with whispered looks the thought passed round in silence,

' This thing can no man bring, nor he were a Jinn in cunning,

Not though on wings he flew.' But Amer in his longing, Swore he the deed would do for sake of her, Betina. And when I learned it all, how it had fared in council, From my poor head the wits, O Sheykh Salame, wandered.

And since that day of trouble-listen, O Helali,Around the world of men have $I$ in anguish wandered, Seeking of kings and chiefs and princes of the Arabs Which one shall help our case, and all in turn have answered,

' This is a deed of deeds meet only for Salame. There is but one thy help, he of Helal ibn Amer.' Thus have I come to thee on my soul's faith, Salame, Thee the champion proved of all whose hearts are doubting,

Thee the doer of right, the scourge of the oppressor, Thee the breeze in autumn, thee the winter's coolness, Thee the morning's warmth after a night of watching, Thee the wanderer's joy, well of the living water, Thee to thy foeman's lips as colocynth of the desert, Thee the river Nile, in the full day of his flooding, When he hath mounted high and covereth the islands. Behold me thus for thee clothed in the robes of amber. Beyond thee there is none save the sole Lord of pity. Thou art my last appeal, O Helali Salame, 
Glory of the Arabs, beauty of all beholders."

Thus then spoke Ghanimeh, and Abu Zeyd made answer,

"Nay, but a thousand welcomes, O thou mother of Amer,

Welcomes as many be as the leagues thy feet have wandered.

Fear thou nought at our hand, nay, only but fair dealing.'

And the hero Abu Zeyd called to his servant loudly : "Forth, O Abul Komsan, nor let thy footsteps linger." And the slave said, "Yes and yes, $\mathrm{O}$ thou beloved of the Arabs."

And he, "Go with this lady and build her a pavilion, With breadths of perfumed silk, and bid prepare all dainties

That she may eat of the best, and serve her in due honour.

For well it is in life to be of all things generous, Ere we are called away to death's unjoyful dwellings, Even of the shoulder meat, that the guests may rise up praising."

And Abul Komsan went and all things set in order, Even as he was bid, at the word of his lord Salame.

\section{Said the Narrator :}

And, when the lady had made an end of talking, then agreed the Emir Abu Zeyd to all her desires, and he delivered her into the hand of Abul Komsan, 
and bade him to do her honour and to serve her in his own person, and not through the persons of others, and he gave him his commands, saying : "Take charge of her thus and thus, the while I go forth and see diligently to her affairs." And Abul Komsan did as he was commanded.

And immediately the Emir Abu Zeyd arose and went into his own tent and took out a herdsman's wallet and a lute, and went forth in disguise as a singer, of the singers of ballads. And thus travestied he came to the Assembly that he might take his leave of the Sultan Hassan and of the rest. And Hassan said to him, "O Mukheymer, whither goest thou, and what is thy design?" And Abu Zeyd made answer, "I am of a mind to journey abroad, even to the land of the Agheyli Jaber." And so he disclosed to him all his plan, both what was without and what was within, the manifest and the hidden. And as he spoke behold the Sultan's countenance changed, and he grew pale, and "Goest thou," said he, "to the land of our enemy, and takest thou from us the light of thy countenance? Leave now this adventure, and we will determine all things as is best for the fair lady." But Abu Zeyd said : "Nay, for the like of me that were a disgrace and a shame, and need is that I go: ay, though I were given to drink of the cup of confusion, yet must I go forward." And Diab said, "May no such disgrace befall thee, nor confusion, for this would be to us all a sign that thou lackedst understanding." And Abu Zeyd 
said, "Lengthen not thy words." And the Kadi calling to the others, said, "My mind is that you should prevent him, even if it were by force, from his purpose, nor let him go." But when Abu Zeyd heard that word of the Kadi's his wrath flamed forth, and he said, "How! would ye deal with me in this wise, with me, the Emir. Abu Zeyd?"

Now the ears of the tribe were filled with these sayings, and their mouths with the noise of them. But none was able to turn Abu Zeyd from his way. And his sister Rih came to dissuade him. Yet he listened not to her words, but soothed and consoled her only, and bade her farewell. And he departed on his quest, going by the desolate vallies of the desert.

Then once more the Narrator singeth :

Saith the hero, Abu Zeyd Salame Mukheymer: "Needs must I haste abroad to the wide breadths of . desert,

What though I fare afar to death's unjoyful dwellings? Constrained of my guest I go to do her pleasure's. bidding."

And speaking thus he turned and went to his pavilion, And clothed himself anew in his most cheerful raiment, Lengthening his kaftan's sleeves and rolling broad his. turban,

Till in disguise he stood, a singer of the singers, With wallet in his hand and lute for his sole armour, But in his head what store of strategy and cunning! 
And thus to the Divan, wherein the chiefs assembled, Crowded all the floor as it were the market of Amer. And when the Sultan Hassan beheld him at the tent ropes,

Loudly he cried to him, "Thou goest forth? And whither?

Tell us, O Abu Zeyd, what meaneth this thy venture?" And I, Salame, said, "It is a thing of honour. A lady came to me, $O$ Hassan, one a stranger, To ask a deed of me, and my own tongue hath bound me.

For when I cried to her, 'What is thy need, O lady ?' She answered, "This I need, the mare of Agheyli Jaber.'"

And the Sultan Hassan hearing, struck his two palms together,

And he cried, "O Abu Helal, thine is a case of evil.

How hast thou staked thy life? Nay, rather leave this daring.

Thine shall the camels be-ay, even the two thousand." And I, "Alas, for shame! Such failure were unseemly. Or will I bring the mare or stand no more among ye, Nay, though my way be death." Then answered Abu Musa,

"Madman thou art and fool. This is beyond thy winning,

Not though thy back grew wings." And I-" Forbear vain pleadings. 
Base surely were the man less prompt to do than promise."

But next the Kadi came and fingered at his turban, And with him Rih my sister, and she called to him, " Helali,

Wilt thou not stay this champion." And I- "Nay, hold thy clamour

Lest I should cut thee short, even with this sword, my sister."

And the Kadi: "Hear, O people. This warrior is foolhardy.

Bring forth the brazen fetters to bind this father of patience."

And hearing, Abu Zeyd was wrath with wrath exceeding,

And his hand set to his sword and "Ho," said he, "ye mad ones!

Talk ye to lay in fetter me who am named Salame, $\mathrm{Me}$, the strength of Helal, who clothed the tribe in glory?

Nay, were it not for shame I would hew ye all in pieces."

And Rih cried, "Woe is me, the burning of my trouble, How shall I quench this flame? Yet shall he take our blessing."

And I, "The word farewell is but a wound to the goer. Cease, therefore, from thy tears." And weeping thus. she left me.

But I my camel mounted and went my way in silence, 
Going by paths unknown in the wide, trackless desert, Nor turned my head again when they had turned back silent.

Thus was our parting done. Shame rest with the gainsayer.

Said the Narrator :

And when Abu Zeyd had made an end of speaking, and the Kadi Diab and the Sultan and Rih, and all had happened as hath been said, then the Emir Abu Zeyd mounted his running camel and bade farewell to the Arabs and was gone, and all they who remained behind were in fear thinking of his journey. But Abu Zeyd went on alone, nor stayed he before he came to the pastures of the Agheylat. And behold, in the first of their vallies as he journeyed onward the slaves of the Agheylat saw him and came upon him, threatening him with their spears, and they said to him, "O Sheykh, who and what art thou, and what is thy story, and the reason of thy coming?" And he said to them, " $\mathrm{O}$ worthy men of the Arabs, I am a poet, of them that sing the praise of the generous and the blame of the niggardly." And they answered him, "A thousand welcomes, O poet." And they made him alight and treated him with honour until night came upon their feasting, nor did he depart from among them until the night had advanced to a third, but remained with them, singing songs of praise, and reciting lettered phrases until they were stirred by his words, and astonished at 
his eloquence. And at the end of all he arrived at the praise of the Agheyli Jaber. Then stopped they him and said: "He of whom thou speakest is the chieftain of our people, and he is a prince of the generous. Go thou, therefore, to him, and he shall give thee all, even thy heart's desire." And he answered them, "Take ye care of my camel and keep her for me while I go forward to recite his praises, and on my return we will divide the gifts." And he left them. And as he went he set himself to devise a plan by which he might enter into the camp and entrap the Agheyli Jaber.

And the Narrator singeth of Abu Zeyd and of the herdsmen thus :

Saith the hero Abu Zeyd Salame Helali :

My tears flowed as I struck the swift one with her bridle,

Turning her to the desert. And fifteen days I journeyed,

Making of fifteen eight, for she was in fleetest training. And running I came to the herds of Agheyl and beheld the camels

Spread like locusts alit, and I knew my travel ended. And lighting I stooped down, and tied her fast by the foreleg,

And looked to right and to left. And presently the herdsmen

Came with the slaves around. And " $\mathrm{O}$ thou Sheykh" they addressed me, 
"Whence and what man art thou? our stranger guest or a prowler?"

And I, "A poet am I, a singing man of the singers, One from his youth afoot, the world's guest, and a stranger,

Singing the praise of kings, the generous souled, the noble."

And they, "A welcome, poet, to thee be eighty welcomes. Make thou a verse for us, display us of thy cunning.", And I, "I hear and obey, a thousand times obedient." And I clutched at my rebab and set her strings in order, And took my bow in my hand, and making preparation Struck the notes for a song of the songs of the Hejazi. And I sang with reiteration, in four and twenty metres, Hymns in praise of the great, the glorious one, the Prophet,

In measured phrase and verse-and afterwards recorded Noble deeds of the world, the gathered sheaves of wisdom,

Giving to each its text. And last I came in my singing To him the generous one, Fadel the Agheyli Jaber. And they cried to me as I sang, "This Fadel is our chieftain.

If but thou go to him he shall reward thee fairly With raiment of all choice, and jacynth stones and jewels, Perfumes and broidered silks, and purple and fine linen." And I, "Quick, hold my camel. Anon will I be with ye." And the herdsmen answered "Ay, and eighty thousand welcomes. 
If that thou bidedst a year, yet shall thy beast find pasture."

And I took my lute in my hand and sought his tent, the Agheyli,

Speaking low to myself, "O thou Hejazi Salame, This is thy day of deceit, the noontide of thy cunning. See to thy stratagems." And I laid my wallet before me, Pondering ways and designs how I might come to my purpose.

\section{Said the Narrator:}

And when Abu Zeyd was on his way through the desert making to himself a plan how he should come into his foeman's camp unperceived, behold him of a sudden in the midst of them. And he saw the men of Agheyl to the right of him, and to the left, and in his front. And with them in their midst he saw a fair young lady, very beautiful to behold, with whom the fairest maidens of the Arabs were in converse. And the maiden turned her eyes to the desert and to the hills, and she perceived him coming. And she sent a young girl of those near her towards him. And the girl met him among the sand dunes and asked him "Who and whence art thou, and what is thy business?" And he told her that he was a traveller, of the pedlars who sell necklaces to the young maidens, and also that he was an hungred. And she brought him food and he ate, praising the Giver of all. And returning the girl told her mistress of his desire to serve her, and she bade him thread pearls upon 
a string and make settings for precious stones. And at once he set him to his work, and the young girl watched him. And he asked of her concerning the tents of her people and concerning the country where she lived. And she told him that the tents were set in three camps apart, and the first camp was for Fadel the Agheyli Jaber, and the second was for his daughter the Princess Alia and for the daughters of the Princes, and the third camp was for the mare. And she praised the worth of the mare and of her owner. And he said to her, "In this mare are there four qualities, and three of the four are for joy, but one is for joy and sorrow." And when she heard this word the girl was very wroth, and she turned upon him and said, "Of a truth thou art no honest guest, but even a spy and a traitor, and for this purpose art thou come hither, to pry into that which is hidden."

And the Emir Abu Zeyd fled to the desert, and to himself he said, "When they of the camp shall be sleeping, then will I return and steal the mare and flee with her away." And night fell, and he sat him down beneath a tree.

Then once more the Narrator singeth :

Saith the hero Abu Zeyd Salame Helali : "Save me, O Lord, from hurt and the contradiction of evil,

Take me, O Lord, by the hand, O Thou who hast power almighty, 
Thou who dost clothe with a veil, be Thou my guard and protector !"

And I asked of the Merciful strength and patience to accomplish,

Walking thus through the land of doubt, a land which is barren.

And I reached my hand to my wallet and found in it things needful,

And I took from it an onion and an egg-shell of the ostrich,

And made a fire on the ground with twigs of the wild willow,

And in a golden bowl I mixed and turned the ingredients. Then whitened I my beard and limned my face in wrinkles,

Lowering my brows a little and darkening one of my eyelids,

And I crooked my back like a bow, a bow bent for the shooting,

And donned my clothes of disguise, that seeing none might know me.

Thus sought I the plains of Agheyl when the sun was near to the westing,

And hunger pressed me hard, for hunger is ungracious, And I cast my eyes around, and lo, like the stars for number,

Stood the tents in their ranks, as it were the Pleiads in heaven,

Each a cluster of stars; and among them a pavilion 
Set for a leader of men; and mares were tethered round it,

And dromedaries trained as it were for a distant riding ; And hard beside a tent of silk, a fair refreshment

To the eyes as rain on the hills, the blest abode of women.

And next in a lofty place, set on a windy platform, As it were a fortress in size, the booth of the great council,

Wonderful in its spread, its length full sixty paces,And tears came to my eyes, for none in the world was like it.-

And all around were slaves. And at the tent ropes standing

Of a house of woven silk of the eighty there together, I saw a damsel proud, the Agheyli Jaber's daughter : Fifty attendants hers, mute girls who speak by signals. And Alia from afar with her fair eyes beheld me, And sent a maid to my help, of the maids that stood around her :

Running she came to me, while her anklets rang and clattered,

And her fair face shone like light, bent forward in her running,

Shone like a moon in the dark, dividing her hair's blackness.

And I prepared my words as a talker doth who is cunning. But she began, "O Sheykh of the Arabs, whence and whither? 
Comest thou here a guest, or one of our foes, a prowler?" And I said to her, "Lady fair, the boon I ask is a breakfast.

I am a hungry man, and hunger is ungracious.

Not till my lips have tasted food can I do thy bidding."

And she answered me, "O Sheykh, to thee be eighty welcomes.

Hungry may no man be in the tent of Agheyli Jaber. Here is of all abundance, and ever the guests uprising,

Praise his name who gave, a stream, a river of plenty.

Wait thou that I may bring what shall not leave thee thankless."

And she left me and returned, and her hands were filled with dainties,

Even with food for kings, meats worthy the world's great ones.

And she stood before me in shame, as it were, a gazelle for coyness,

Offering dates with her hands and butter and milk of camels.

And I put my hand to the dates and still she pressed me ever;

And I drank of the milk my fill, she bidding me still welcome,

Health and a thousand welcomes, and last she asked me my story. 
And I said to her, "Ay, truly, thy mind will I enlighten."

And she said, "Speak truth and tell, Art thou an honest walker,

Or one that prowleth around ?" And I told her my condition,

As one a stringer of gems, a necklace-maker for damsels. And she went and came again, and "Thus," she said, "saith Alia,

Wouldst thou rejoice her heart, then weave her a chain of value."

And I, "Then bring the wool, the first shorn of the camel."

And she brought me all I desired, and I wove the necklace fairly,

Linking it like a chain. And I laid the threads together

And ended all with a knot, and I strung it thick with rubies,

Reciting still as I wove new texts from the Holy Scripture.

And I charged her that her mistress should wear it night and morning.

And she went and she returned. And "Thus," said she, "saith Alia:

Since that the night is at hand do thou remain in our dwellings.

Meat is for thee and raiment." And I, "As thy queen desireth. 
Yet, $\mathrm{O}$ thou fair one, say, Whose house is this pavilion? And who the warriors round? Belike they guard them a treasure."

And she, "That is nought to thee, so thou be an honest walker.

Rather hold thy peace, lest these around suspect thee. This is the tent of Alia, and that of the Prince Agheyli, And that the third, apart, of the mare of Agheyli Jaber,

The grey mare, the renowned : in the world there is none like her,

Not with the Persian kings, the Chosroës, the Irani. Spare is her head and lean, her ears set close together; Her forelock is a net, her forehead a lamp lighted, Illumining the tribe, her neck curved like a palm branch,

Her wither clean and sharp. Upon her chest and throttle

An amulet hangs of gold. Her forelegs are twin lances.

Her hoofs fly forward faster ever than flies the whirlwind.

Her tail bone held aloft, yet the hairs sweep the gravel; Her height twice eight, sixteen, taller than all the horses.

Here are her virtues told in full enumeration-

Dear to her master's eye as gold and precious jewels." And the grooms who heard her said, "Let not this guest despise her." 
But she, "Nay, verily ; so ye but fasten the hobbles." And Salame heard their talk and smiled, this prince of deceivers,

And he said, "O maiden, hearken. I have a thing for thy hearing.

So thou but speakest truth, the mare is indeed of the coursers.

So thou but speakest truth, then are three flames extinguished,

But of the fourth, the fiercest, behold thou stirrest the embers."

And the damsel heard him speak and answered straight in anger :

"Bitter words are these, O Sheykh, as the edge of a dagger.

Nay, by thy tongue I know thee, thou art no Sheykh of the great ones;

Rather a prowler around, a spying thief of the campfires;

One with a heart of blackness seeking our queen of coursers.

Verily this thy speech betrayeth thee for a traitor;

Verily she who hath ears hath heard thy words in amazement.

Spying the land thou art come a traitor-guest to our pastures,

Spying and stealing away the mare of Agheyli Jaber. Thus have I read thy riddle, the sense of thy dark saying. 
One to thy ear hath been and told the fame of her glory,

Covetous-sick of the mare, in longing night and morning,

Till thou didst rise and spread thy cunning nets for her taking,

Hoping to win renown and hie thee home to thy people.

These three things thou hast shewn, the quenching of thy heart-flames,

These three things, and the fourth to fire the wrath of her owner;

Thus read I thy riddle, thy idle words I interpret.

Now therefore take this counsel, get thee gone from our dwellings.

Fly for the life thou hast nor linger here for its losing; Fly ere I send thee forth to death's unjoyful dwellings; Fly ere I spread the word and bring the Arabs upon thee,

Mounted on steeds of speed to question me of thy doings; And I shall tell them truth, and yield thee to the spearpoints,

Nor shalt thou succour find nor any to show thee pity."

And Abu Zeyd was grieved for what he had said to the damsel,

Yet took he courage and cried, "Enough of this fool's talking.

Never may fate befriend me if it have sense or meaning. 
$\mathrm{Ha}$ ! the mare, what is she that I should wish for or win her?

Never in all my days have I bent my leg to a saddle, Being of those unskilled, and little apt in the learning." He spoke, and rose to go in anger, he the dark one; And she too to the camp, to her own tribe and people, Even to Alia's tent. But presently Salame Passed on his way in doubt and fear and consternation, Thinking of those her words, hers with.the plaited tresses,

And, "O thou," to himself he said, "thou innocentminded!

Thou forsooth the father of wiles, the old deceiver! How hath she laid thee bare and cozened thy beguiling, Reading all thy thought and making plain thy plottings! And she is gone from thee, and thou art alone unfriended,

A stranger among foes, and who shall give thee shelter?"

Then on his musing fell the depth of night and of darkness,

And still Salame pondered grieving his black fortune. And when it was fully night he cast his eyes in a circle, Where he might win a lodging in the wide, naked desert.

And he spoke again to himself, "Salame, thou the Hejazi,

Now is thy hour to do, the occasion of thy cunning, For well hath the poet sung, he, Ibn Arus the singer, 
'The black night fell on the world, and lo, in its trail the prowler.'

And musing thus he passed beyond the farthest campfires,

Till lo, a spreading tree at his hand with low-set branches. And Abu Zeyd rejoiced and entered within its borders, "And here," said he, "will I rest, and sit me down till the midnight,

Even till the break of dawn when the camp shall be unguarded,

And I in my steps may turn unseen and all things accomplish,

Making prize of the mare, and so to my own people."

Said the Narrator:

And when Abu Zeyd had sat him down beneath the tree, behold him in a great anguish and trepidation and sorrow. And to him presently waiting thus there came a form approaching through the darkness, and he was astonished, and he said to himself, "What can this thing be? Climb rather, thou, $\mathrm{O} A$ bu Zeyd, into this tree, so that thou be hidden and learn that which shall come about." And he climbed into the tree's branches like unto a raging leopard and watched narrowly the coming of the man, who stopped beneath the tree. And the comer was Sahel ibn Aaf; and Sahel waited looking ever to the right and to the left, and so till a third of the night was over. But at the last there came to him a lady, an exceedingly fair woman, and her name was 
Zohwa, the daughter of Nasser the Agheyli. And these two had between them an understanding of love, and he had promised that he would come that night to the tree, and she that she would meet him there. And he had waited long for her coming, until his heart was on the boil with his love and with the fire kindled within him. And he, even when she was come to him, believed hardly that he saw her with his eyes. And he went out to meet her and he asked her the reason of her delay. And she answered, "I waited for the eyes to sleep and until my father and my mother should be in their dreams, and as soon as they slept I came to thee. And now do with me all that thou wilt, for I am here before thee, nor am I miserly of my regard." And on hearing this he forgave her, and he kissed her face, and she kissed his face, and they sat down and began to discourse together, Abu Zeyd the while crouching above and listening to their words. And he had a mind, for shame's sake, to slay them both; but he said to himself, "Let us first see how it shall happen." And they fell to talking of the gossip of the Arabs, and presently they spoke of Alia. And Sahel became troubled and he said to Zohwa, "O that I could behold her! O that thou couldst bring her hither!" And she asked of him, "Why so? Is she then more beautiful than I? Are her eyes more fairly painted?" And he said, "Not so. But listen. I have had with her an adventure. It happened to me thus, that I was abroad in the desert and that I came to a certain fountain of sweet water, even that fountain in 
the which if one shall wash his garments he shall remain ever in health. And, as I approached it, behold the daughters of the princes of Agheyl seated on the banks of the stream, and their hair was loosened from the plaits, and I saw that their hair was dark as the descending night and that their eyes were painted with kohl. And looking thus and perceiving their beauty I became as one bewildered, nor could I turn away my eyes but remained staring and gazing, until at the last one of them was aware of me and called to the others, "Cover your faces, $\mathrm{O}$ girls, for there is a man hard by and I have seen him." And Alia turned and saw me. And her anger was lit and she unloosed her tongue against me. And the others besought her that she should tell all to her father; and so turning they left me in great fear and apprehension of the trouble that might come of it. And I threw myself upon my face in the desert and I resolved that I would not return to the tents, for I mistrusted that Alia would give news of it to her father, and that he would seek my life and give me to taste of the cup of evil things. And so truly spake she of it to her father and told him all as it had happened. And he went out against me and came to my tent, and finding me not he slew my father in my place, and afterwards made it known that whosoever should find and kill Sahel the same should receive of him a reward, even all that he should ask for. And now, O Zohwa, I have but this one desire, to avenge the blood of my father by her destruction and to soothe my soul with slaying her, 
and after that I care not what may come, not though they hew me to pieces with their swords. And surely the news of her death at my hand would travel abroad and grieve the heart of Fadel and wound him so that he too should die."

And when Zohwa heard this story she bade him to be of good comfort, for that she would bring him to his heart's desire. And she said, "I will fetch thee Alia hither, and in a short space, for this is no far-off matter. Wait only until I return to thee, for see, my soul is not niggardly to thee of its regard."

And she left him and returned to the tents, and she sought the pavilion of the Princess Alia. And Alia, when she saw Zohwa, rose and went forward to meet her and made her sit beside her and inquired the cause of her coming. And Zohwa said, "O my lady, I am in a great perplexity, and therefore am I come to thee." And she sat down beside her and told her a long tale of trouble and kept her thus talking through the night, and soothed her with soft words, deceiving her and flattering her with fair speeches of praise until she touched her heart with her cunning, nor did she cease from discoursing until a second third of the night was spent and there remained but these two awake of all the camp which was sleeping. Then Zohwa arose as if to go and she asked for leave to depart, but Alia besought her that she should stay with her and sleep there in the tent beside her. And Zohwa said, "Of a truth that would be before all things pleasant and for an honour to me, but 
I have been at pains to escape unperceived from my people and to them must I return." And Alia hearing, was moved to pity and she said, "Go then." And Zohwa went out of the tent and on a little way, but presently returned trembling as a ship trembles when it is struck by the wind, and she showed manifold signs of terror. And Alia asked her, "What aileth thee then?" And she answered, "O lady, I am overcome with lack of courage. And surely thou art responsible for me; but wilt thou not come with me a little way?" But Alia said, "Nay. For if I should go with thee, who afterwards should return with me? And see, the guards are sleeping, and my damsels every one of them. Nor am I too without danger of enemies who might do me a hurt, and, more than the rest, of that dog Sahel ibn Aaf." And Zohwa answered quickly, "Say not so, O lady. And how should Sahel hurt thee, or how should any other, seeing that thou art the daughter of the prince of our tribe, the greatest of the princes, whose fame is in all the valleys? And yet thou speakest thus, thou daughter of the generous? Nay, it is no far journey. Listen : between thy tents and ours are but ten furlongs, for the space hath been stepped by the trackers, and if thou wilt come but one-half the road thou canst then turn back and I will go forward, and the way will have been thus divided between us and each will have accompanied the other and fear shall have been outwitted." And Alia stopped at this agreement, for her wit failed her. And she arose and went with Zohwa out of the camp. 
And Zohwa's tongue wagged as they walked so that the way seemed short, and Alia lost reckoning in the darkness. And thus they came to the headland which stood at their mid-journey. And Alia knew nothing until, coming near the tree, suddenly Sahel leaped forth upon them. And Alia knew that it was he, and she cried aloud in fear. But Sahel seized hold of her by her neck ornaments and swore that if she cried out he would even cut off her head. And he began to use base language, and he said, "Now will I be avenged of the blood: and by the faith of the Arabs need is that I shall slay thee." And she said, "To thy honour I appeal, O Sahel. So may God requite thee and save thee from the rage of Abu Zeyd the Helali."

And her heart became straitened, and her tears overran her cheeks, and she knew that that traitress had entrapped her. And she entreated him, saying, "First only let me recite the prayer, that the pang of death be assuaged." But he laughed at her words, and said, "If thou be of the blameless, pray on." And he went to Zohwa and kissed her, and Alia beheld it and wept at what had befallen her, appealing still to his honour. But he treated her scornfully, saying "Dost thou not know him, this dog, this dog of dogs, this wolf, this slave, this jackal of the great? If thou hadst him in thy hand thou wouldst surely make him to drink of the cup of evil things. Now therefore, behold, there is no escape for thee from the hand of the slayer."

And when Alia heard this she sundered herself from 34 
created things and turned her soul to the Recompenser and the Avenger, and her prayer was not hidden from the Maker of the Earth and from Him who upholdeth the skies. And she prayed with her arms extended. And the Princess Alia did not cease from her prayer to her Lord until Sahel had drawn his sword from his sheath and was pressing on her to seize her.

And she cried out: "To my help, O Arabs! To my help, O strangers!" And suddenly a semblance and a form swooped down on them from above, as it were the coming of a lion from the tree. And behold, one with a drawn sword exceeding sharp, who cried, "Haass! Haass! Hold off from her, thou base born of the Arabs!" And when Sahel saw him his understanding left him and he was as one dazed and Zohwa with him, and they trembled. But Alia rejoiced, though she knew not from whence this champion had come down to her. And Abu Zeyd struck Sahel ibn Aaf so that his head fell back behind him. And the girl too he took and slew, and cast their bodies into a hollow place that the beasts of the field might devour them. And when he had done this he returned to Alia and undid her hands. And he bade her return to her tent and tell no man what had happened to her, of her people.

And the Narrator once more singeth :

Saith the hero Abu Zeyd Salame Helali :

For that which befell that night have my tears flowed unceasing, 
For that which that night befell, as I alone in the desert Turned to the right and the left my eyes (they are no deceivers),

For I saw one come to the tree as though in search for a shelter.

And I said to my soul: "O soul, climb thou and watch the achievement."

And my soul swung lightly aloft, and lay in wait in the branches.

And he came as if to a tryst with one of the daughters of Adam,

Even a tryst, $\mathrm{O}$ people, with one of our fairest daughters. And an hour passed, and behold a lady too in the darkness,

Who said "Be thy evening good, $\mathrm{O}$ son of a noble father."

And he, "Two thousand greetings to thee and tokens of fortune.

These-but what hath delayed thee, alas! thou daughter of Nasser?"

And she said, "O worthy of praise, $O$ Sahel, I watched and I waited,

Even till all should sleep, my father first and my mother, And one by one my sisters and brothers. But when night held them,

And all lay fast in the fetters of sleep, I arose for thy pleasure."

And Zohwa came to his side, and they sat on a mound together, 
And he, the dog, looked into her face, and each the other's

Neck with their arms embraced. And I said to myself "Salame,

Wait thou in patience on (for he who hath seen is the wiser),

And hear of them their tale and learn the fate and the judgment."

And their talk was of their neighbours. And anon he spoke of Alia.

And she said, "I will bring her hither that thou mayst fill thy vengeance,

Thou shalt be quits with her, with her of the plaited tresses :

Even to-night will I bring her. But tell me first, and truly,

Are her eyes darker rimmed than mine, more kohled, more painted ?"

But he, "Nay, nought of this. The trouble is far other.

Rather list to my tale of woe and of strange adventure, A tale of fear and pain, a brimming over of trouble.

For thus it was, to my hurt one day on my best courser Rode $I$ forth to the spring, the fountain of Ridaa, There be there pleasant winds, full scented with rich odours,

Sweeter than scent of flowers; and if a garment touch it, Ten days and more with musk shall it remain in fragrance. 
Forth by the dales I rode and travelled in my yearning, Till to my gladdened eyes behold, the fount Ridaa, And at the waterside the damsels and the daughters, Alia with all her band. And hence my earliest trouble. For I saw them there unseen, this goodly band of damsels,

Dark, with their hair unbound, and those fair moons, their faces,

(For some were as crescent moons, some half moons and some full moons,)

With brows divinely knit for their sad lovers' dooming, And eyes aflame to smite and pierce his soul like lances, And red cheeks, every one a rosebud newly blossomed, And noses curved and keen and finely shaped as sabres, Sabres upheld aloft in the skilled hands of swordsmen, And mouths like lover's knots, and teeth agleam like jewels,

And necks, the wild roe's neck, on lavender new pastured And shih and all the herbs, the sweetest of the desert. By this was I undone. And one of the maidens saw me, Sprang like a fawn in fear, and called to her companions, 'Alia! Ho, ye damsels, daughters of the great ones! Here is one watching us, one spying in the desert.' And all looked up and saw where I stood plain, unhidden. And Alia cursing, cried, ' $\mathrm{O}$ base son of perdition, Evil be on thy head.' And they called to her and questioned

-Who, then, is this bold man, hath dared be thus familiar 
With us the noble ones, the daughters of the Sultans?' And she said, ' $\mathrm{He}$ is none but Sahel, Sahel the son of Aaf,

He of the evil word with sole shame for his fortune.' And they bade her go to her father for that the prince might know it,

And so take vengeance due. And Alia straight departed. And the sun had hardly risen e'er he, the lady's father, Fell on my sire with the sword. And I fled before his anger,

Weeping, to lands afar, and stripped of all, an outcast ; For Jaber took our herds and servants and possessions, Two hundred fair milch camels, and my red mare, the swift one ;

And twenty months have gone since I beheld my people Or knew the sweets of home. O Zohwa, shouldst thou bring her,

This Alia, to my power, thou shouldst behold a judgment, A tale of death for her, and for her father sorrow,

Noised on the tongues of men till the last day of dooming."

And she, "I hear and obey, a thousand times obedient. Death shall be surely hers, and a supreme destruction." And he "Then compass thou the occasion of her coming."

And she, "So shall it be, thou glory of beholders." And he, "Be up and doing, for lo, the short night waneth." And she quickened her pace and went and came to the tent of Alia. 
And she drew the curtain aside and Alia rose to greet her:

"Welcome to thee, O Zohwa, welcome, thou daughter of Nasser,

How doth it fare with thee? Thou comest on what errand?

Speak, what thou wilt is thine, even all thy heart desireth."

And Zohwa spoke dissembling, "My duty brought me hither,

This and my love for thee and my great debt of reverence.

I came to-night to thee in thought to do thee service, For fair discourse of friends is to the soul an unguent." And Alia bade her welcome, ay, even eighty welcomes, And made her entertainment, for her heart smiled within her.

And Zohwa clothed her words in garments of affection, And so talked through the night, two thirds of the night; but after

Rose she and bade farewell. And Alia pressed her nearly,

"Wilt thou not bide with me, for see, the short night turneth,

Hardly an end is left, thy couch shall be spread quickly." And she protested, "Nay, of a truth I dare not linger, None know that I am here, of my own house and people; Rather, if there be kindness, come with me thou a little, 
Half of my road, with me, $\mathrm{O}$ thou of the beautiful necklace."

And Alia "Nay, in the night I too have cause of danger; The son of Aaf is my foe. Sahel, I fear him, the plotter." And she "Who is he, this man, this dog of the sons of the Arabs,

That thou shouldst fear his intent who art the daughter of Jaber?"

And Alia, hearing, arose and went and stood by the tent ropes

And lingered there without, while Zohwa with false phrases,

Wiled her still to her way. And she said, "My heart forbodeth,

There is one lying in wait, even he the son of perdition. Let me return within." But Zohwa, "Wherefore fear him?

Is not thy father's name a terror in all the marches? Shail it not shield thee from ill, though sooth the wicked be many?"

So they went forth together. And Alia's eyes misgave her

Seeing a form in the dark. And she called out "What thing art thou?

Art thou a passer by, or one with intent a prowler?" And he, the approacher, said, "Now truly art thou taken,

Captured as in a net, and the Maker of Earth and Heaven 
Yieldeth thee to my hand and blindeth thee to thy peril." And Sahel begun to curse her, and to the tree he drew her.

And she knew her hour was come, and her heart within was shaken.

And he clutched with violent hands at her necklace as for strangling,

Till at his feet on the stones she fell. Ah! pitiful maiden.

And he bound her with cords and cried, "Confess thy faith e'er thou diest."

And she entreated him, saying "O Sahel, wilt thou not

spare me,

So may the Lord requite thee." But he, "There is no sparing."

And to Zohwa she cried "This is he I feared, the son of perdition,

And thou thyself art deceiver." But she answered her with tauntings,

" $\mathrm{Be}$ it so, I deceived thee. Go to. We shall see this Sahel

Prove himself of his skill when he loppeth thee, legs and shoulders."

But Alia prayed to Sahel, "Do thou recite the Fatha, So shall the cup of death to my lips be found less bitter." But he answered, "Wert thou blameless, so truly would I recite it ;

The Fatha is not for thee." But she wailed aloud and lamented, 
"Alas, what death is mine. And, if he were here, my father!"

And he asked: "Who then is he, thy father, $\mathrm{O}$ thou proud one!

Nay, but humble thyself." But she called the more, "Oh, hear me!

God will visit this sin on thee and on her, ye traitors. Do thou but grant my demand and make my death less bitter.

For he who dieth not on the day shall fall on the morrow, And he who scapeth the sword, the same by the spear is smitten,

For all things have their days and courses and appointments."

And he said, "I grant thee respite. And after will I smite thee

And give the death thou fearest." And he spoke aside to Zohwa,

"Sit we awhile apart." And Alia raised up weeping Her beautiful eyes to Heaven, and she prayed to Him who hath pity,

"O Thou searcher of hearts," she said "who knoweth the secrets

Even of every heart, to Thee I look for compassion. Thou the merciful One, the Eternal, the most Mighty, Thou who art of Thyself, the giver of consolation, Thou the pitiful One, to Thee I come in my sorrow, Calling on Thee by the name of Thy deeds, the might of Thy wonders 
Done for those Thou didst choose to Thyself against unbelievers.

To the prayers of the just I appeal that Thou protect me and succour,

Staying the hand of the wicked man the son of perdition." And to Ibn Aaf she said, "I appeal to thee of thy honour,

So may the Lord thee spare, and heal thy soul of its blindness,

Guarding thy head from the day of wrath, the spear of Salame,

From Abu Zeyd the dealer of blows, the lion avenger." But Sahel answered, "Nay, by the Prophet I will not spare thee.

Not though Abu Zeyd were here himself the Helali. For what is Abu Zeyd? Let him help thee, thou dog's daughter!

Let him deliver thee from my hand, thou daughter of Jaber!

Are we not, we the Agheylat, secure in our pastures? $\mathrm{He}$, the Helali foe, where is he? In some far dirra, Pasturing flocks of his own. He shall not help thee nor succour."

But she, "Yet if God so willed he were here even now upon thee."

And Sahel, "Hold thy peace, for to-night thy life hath ending.

What shall Salame do to thy help in these our pastures? The wolf is not as the lion in the manner of his seizing. 
Were he here, Abu Zeyd, even now in this hour of speaking,

Him would I smite to death and leave in his blood to perish."

And Abu Zeyd from the tree heard all the words between them,

And my mind rose to her help as a full pot boiling over.

And I heard my name in their mouths, and my heart grew hot within me,

Like a pitcher from the well which brims and spills with fulness.

For why should Sahel slay her, and I not stand between them?

Sahel his sword hath drawn and leapt on her with cursings The while she cryeth aloud. But I too cried, "Take courage.

Lo, I am here to thy hand, one able for thy burden." And of a sudden I dropped and ran to the three that struggled.

And Sahel I seized by the throat and dragged towards destruction.

And he cried, "Who art thou and whence and what the way of thy sending?"

And I. "From Death the King am I come to take possession.

Life is weary of thee, and Death's edge presseth nearly." And he, "O Sheykh of Afrits, wilt thou not spare the sword stroke, 
Lo, I turn from my sin in thought of the day of judgment."

But I, "Thou art but a heathen. Thou didst refuse the verses.

Thou hast denied Our Lord. Thy heart is an unbeliever's.

Thou hast done a treacherous deed. Thou hast angered thy Creator

Purposing death to souls, and therefore will I slay thee. For were it not for this, thy infidel denial

Thus in act of thy God, my hand should spare to smite thee,

Since that I love not strife nor is there blood between us."

And I put my hand to my sword and drew it from the scabbard,

And it flashed as lightning flasheth, making a flame in the darkness,

And I smote him with its edge and his head flew from his shoulders.

And turning next on Zohwa I smote her too, while Alia Watched with the eyes of thanks the issue of the sword stroke.

And I severed the cord from her wrists, and she rose and took her bracelets.

And I bade her go in peace nor speak a word of the doings,

When morning light should come, to tribesman or to kinsman, 
For ever the mouth is blest that holdeth its own counsel.

Said the Narrator:

Now when the Princess Alia had made her petition to the Maker of the Heavens, and her deliverance had been wrought by $\mathrm{Abu}$ Zeyd with the slaying of her enemies, and he had said to her "Return and say no word of this to thy friends," she besought him, saying : "Nay, but by Him who commandeth all power, I will not return home until thou hast told me of thyself, who thou art and of what tribe and nation of the Arabs." But he said to her, "Know, O Lady, that I am of the race of the Jinns and that our people are indeed Muslims obeying the Lord of the Universe, and I was sent to thee from the land of Syria to deliver thee from that traitor, who was of the children of crime." But she answered him, "Yet are not the Jinns of thy quality. Rather tell me the truth. I adjure thee by Him who created thee and in whose shadow thou didst grow up, and who hath wrought blessings through thy hand." And being thus adjured he said, "O Alia, there were peril for me if I told thee truly all." But she answered, "Be not afraid. Though thou wert the Prince Abu Zeyd himself, the Helali, yet shouldst thou have security, ay, even he that great horseman." Then said he to her, "Stretch forth thy hand that we may make a covenant together, so shall God be our witness." And she said, "As thou wilt." Then they made them a covenant 
together in the name of God the Almighty, and their souls were loosed of their burden. And Abu Zeyd spoke to her and told her all, and said, "It was indeed none other than I that slew thy uncle, nor came I with a better purpose than to steal away that mare." And she said, "Now is my heart light and my trouble ended, and as for the mare, look for her at my hand and not through another road; for my uncle and my people, are they not at thy disposal ? and if there hath been evil how shall we take vengeance now, for I and my wealth and my kindred, all that is mine is thine. And thou shalt not find us niggardly of our kindness to thee, nor shall we refuse thee aught, inasmuch as all that I might do for thee, whether I fast or whether I pray, whether I give or whether I bestow, never might I make up to thee for what I have received at thy hand. Therefore shall there evermore be kindness between us. Ay, and if thou be willing, come thou now to our camp." But he said to her, "O Alia, O fairest lady, know that this I cannot do, this I desire not." And when Alia heard this word, it deepened her regard for him, and she praised God who had ordered it that she should meet with one so honourable. And she perceived that to one such as was this brave knight she could entrust her soul and all that was hers. And she entreated him, "Come with me to the tribe." But he, "Never can I come with thee." And still she besought him, saying, "Know this, O Hejazi Salame, that I will not leave thee here nor depart from thee. And as to the mare, her will I deliver to thee $4^{8}$ 
and whatsoever else thou demandest. Nay, though it were my soul I would not deny it." But he answered her, "My mind is changed about the mare, nor would I now take her, for I fear lest they seeking and not finding her should suspect thee, $\mathrm{O}$ Alia, and trouble should come to thee of thy father. And have we not the grey mare of Diab with us, the Shohba, whom we may give to the lady, nor run this great risk for her sake?" But Alia insisting said, "Nay, that shall not be, nor care I what may come, not though I should taste of the cup of evil things. But if thou wilt not take the mare, then will I kill her and myself with her, and on thy head be it for her and for me." And Abu Zeyd consented, saying: "I will do what thee seemeth good. So may God prosper thy designing."

And the Narrator returned to his singing of that which happened between the Princess Alia and the Prince Abu Zeyd.

Saith the hero, Abu Zeyd Salame Helali :

Thus was our meeting made, mine with the Princess'Alia. The cause in the beginning of all was a mother bereaved,

A mother who came in her need where I sat with the chiefs assembled,

And told us her desire, the mare of Agheyli Jaber. And I pledged my soul to her prayer I would bring the mare, and straightway.

Went I forth nor tarried, seeking his tent the Agheyli. 
And I made my plot to entrap her, standing unknown among them.

And how I came to this tree she knoweth it, Jaber's daughter,

And how with my hand I snatched her life from the hand of the wicked.

And I said to her, "Lady, return and be content with thy fortune,

Speak no word of it all, of that which hath befallen,

Keep thou close thy secret. So shall they do thee honour."

But she, "To return were grief, $\mathrm{O}$ dark one, sweetest of faces,

Nay, by an oath I adjure thee, even by the House, the Kaaba,

Tell me thy tribe and dirra, and who be thy nearest kinsmen."

And I, "I hear and obey. With the Jinns am I in kindred. Kings are we of the great, Berkhan is my father's brother, Shemhurish and Tayar are next to me for cousins."

But she, "Not so, the Jinns are not of thy human nature. Tell me the truth of thy tribe, and which of the sons of Adam :

All that thou hidest speak." And I said to her, "Behold me,

Now will I tell thee all (and may the deceivers perish). Behold me, him who came to string for thee thy necklace, And thou gavest him dates to eat and for drink the milk of camels. 
And thy damsel chid me saying, "There is no nobility in thee,

By my faith thou art no Sheykh, rather a spy and a traitor.'

And I was afar in Sham at the evening hour when thou calledst,

Crying aloud for help, and I snatched thee from thy peril." And I said, "Now go in peace, thou daughter of the Princes."

But she held me by the neck and stretched her arms entreating.

"Tell me thy tale," said she, "for know, I am Jaber's daughter ;

Why shouldst thou fear to speak? Tell of thy tribe and people,

And peace be with thee ever, even to the day of judgment.

Alia am I of Agheyl, and Fadel is my father:

First of the horsemen he, the mightiest, the most noble, And my mother's name Kanua, one of illustrious lineage. Tell me thou of thy Arabs, thy house and thy connection,

So shall my heart be at rest." But I, "Alas, O Alia, What if the news should fly, and thy tribe slay the stranger?

Stretch forth thy hand to me, in covenant between us, Whoso then shall betray, let him be as an unbeliever." And I stretched my hand to her hand and touched it with my fingers. 
And its softness made me wonder, and its most slender fashion,

And the palm of her hand in mine was cool as a cloud in summer.

And I placed the veil between us, and we held fast by the girdles,

And I recited the oath and sealed with a prayer our treaty.

And I cried aloud, "I am Abu Zeyd, he and no other, Salame, chief of Amer, the slayer of thy kindred.

For I slew Zohan, and Abu Tolh, and Fakhr, and Khodel,

Leaving their kith in pain with lovelocks shorn from their foreheads.

Mine is the arm of valour which made Helal victorious, Mine the vow of succour to all in need distressful." And Alia heard me speak and stood up tall before me,

Like to one making a cry, but I shut her mouth with my hand's palm.

And hot tears came to my eyes, and "Cry not," I said, "O Alia,

Cry not for pity aloud, lest I fall in a sea of trouble." And she said, "My cry was unwilled, for thy love my whole heart filleth,

And now fear is forgot. And O, Abu Zeyd Salame, Know that we twain must love, for I am of noble lineage,

Even as thou thyself, the hero, the lion of Amer." 
And I said, "Now listen, Alia, to that which I would tell thee :

Love is a building fair, broad based on sure foundations. And the builders built it high as was no other dwelling."

And she said, "Thou speakest truth. And love is of three conditions,

And to men of understanding each hath a sign to know it.

The first compelleth thee to kiss the hand thou lovest. This is a moment's love. The next is more enduring, Which kisseth thee on the cheek. But there is yet the latest,

Love which shall kiss thy forehead. This is a love for ever.

Mine is of all the three. And for my soul's consoling, Come thou to our camp." But I said to her, "O Alia,

In this thou art to blame. I dare not on such venture, Being a seeker still of that which was my questing." But she said, "The mare is mine. My own hand shall unloose her.

With me are her hobbles' keys, by night will I unlock them.

The keys lie in a goatskin, a goatskin filled with water,

And that deep in a well. There lieth our secret hidden. And all are mine to deal with, goatskin and keys and hobbles. 
Therefore do thou give ear-nay, be not thou despising.

For as the mare is mine, so am I thine to deal with. Let us arise and go, thou, I, and the mare together, Even to thine own tribe." But I, "My thought is elsewise,

No more I seek the mare, nor is my mind to take her,

For have we not the Shohba, the grey mare of Ibn Ghanem?

Her will I give in ransom for the mare of Agheyli Jaber.

Nay; for I fear for thee, lest evil should befall thee, Through the tracking of the mare, thou daughter of the great ones,

Evil and sore disgrace which all men should remember." But she said, "No, of a truth. And, if thou spare to take her

Then will I slay her straight. For how many more beside her,

Stand not tied at our door, mares like to her in value? And for myself, alas, the poison cup stands ready, And I will go with her to death's unjoyful dwellings." And when I heard this word, need was that I consented.

Said the Narrator :

And when the Princess Alia and the Emir Abu Zeyd had finished talking in the manner told, and she 54 
perceived that his mind was truly on the mare, and that for her sake only he doubted, then answered she him thus and said, "Behold, I will arrange this thing for thee, even if in its accomplishing my soul should pass away, for in truth the mare is precious to my father, more precious than am I his daughter." And Abu Zeyd, hearing this, pondered a long while, even for an hour in silence. And she asked him, "What aileth thee, O Helali Salame?" And he said, "If I should take the mare, of a surety thy father would question thee of her, and he would learn the truth, and maybe he would treat thee ill for her sake. And for this cause hath my mind changed that I will not take her. And there is verily the grey mare of Ibn Ghanem, the Shohba, and her we could put in her place." But she said to him, "Nay, that may not be, not though I should drink of the cup of bitterness. And, if thou dost not take her, surely will I slay the mare and my own self after her, and thou alone shalt be responsible to her Lord and to my Lord. So come down now this very hour to the camp, and I will arrange all the matter." And he answered her, "Do thou go before, and I will follow after thee on the morrow." But she said, "Nay, but come thou now with me." And she desisted not until he came with her to the tents. And she made a place for him of honour on a rich carpet, and she herself ministered unto him, speaking him words of welcome. And she brought him the ewer, that he might wash and pray. And for 
this he praised God. And he needed sleep, so she said to him, "Sleep here in peace, for I am mindful of the covenant made before God between thee and me." And he slept. And this was after that he had eaten and drunk, and refreshed himself. And behold the dawn lightened. And Alia brought him water, and he prayed. And she brought him something of food, and he praised the Lord of all creatures. And she set him in the seat of honour, and she hung around him curtains of silk, and he slept. Then she left him and went to the Assembly.

And the Narrator once more singeth :

Saith the hero Abu Zeyd, the Helali Salame : Of that which befell, $O$ people in wait for information, Hear and list to my words, "O Alia, daughter of Jaber, Leave me here and go thy way to thy tribe and people.

Leave me here. With the rising sun shalt thou see me coming."

But she, "O Abu Zeyd, thy life with mine is knitted. Thy soul is as my soul. Be not for me in trouble." And she set her hand on my neck, and held me and implored me.

And I, for all I feared, went home with her unwilling. And she led me within to a couch, a couch spread soft with cushions,

Four-square with curtains round and netted thick with jewels, 
(A castle you had deemed it) -and she said, " $O$ thou Salame,

Now hast thou made us glad - for see, the tribe rejoiceth. To-day is white through thee, $\mathrm{O}$ prince, $\mathrm{O}$ lion of Amer."

And she brought the basin and ewer, and stood there in her beauty,

Shining, unveiled, her hair in plaits which hung to her girdle.

And I washed and prayed alone, as is ordered by the precept.

And anon she came again, and in her hand she brought me

Somewhat that I might eat, meats fit for kings, in dishes.

And she said, "O Abu Zeyd, there is time if thou wouldst slumber.

And she spread a bed before me with her own hands for sleeping;

And sprinkled it with musk, sweet-scenting all the chamber.

And she of the plaits returned, and yet again, with coverings,

Like a gazelle, I deemed, the wild fawn of the desert.

And her eyes! May God be praised if thou shouldst gaze within them!

A bird as it flew might fall, from its midmost way beholding. 
And on her cheek a dimple guarded near with roses. And wrists and hands how soft! Glory to Him in heaven,

Who fashioned thus her beauty, this daughter of the great ones.

At the break of dawn she came, her countenance all shining,

And she brought me the ewer filled, and I made my supplication,

And praised the Lord of Might, the Merciful, the Creator.

Said the Narrator:

And when the day broke and Abu Zeyd had made his prayer, and Alia had entered and bidden him good morrow, and had said, "Thou hast made us glad, $\mathrm{O}$ Abu Zeyd, with thy presence," and he had answered her, "God bless thee," then came she to him with food and he ate, and he arose. And she set out the couches and put all in order, and commanded that the drums should be beaten to summon her young companions, and she said to them, "Rejoice with me, and prepare of all things in abundance, for a great happiness hath come to me and the extreme of favour." Then sat they all around her and made display of joy, and all care vanished. And when the damsels were complete in their number, then returned she to the Hejazi Salame and said to him, "Come, take thy place with me in the Assembly of the daughters of the Arabs." But he said to her, "O Alia, $5^{8}$ 
my desire was that I should remain secret, and behold thou wouldst make all things known." But she : "What matter? Fear nothing, for the souls of all of us are thine, and no harm shall befall thee, and we are a ransom for thee." So she brought him with her and set him on a throne of gold by her side. And, when the daughters of the Arabs saw that, they looked the one at the other and whispered among themselves. And the Emir Abu Zeyd wept aloud and lamented. And Alia perceived that he was weeping, and asked of him the cause. And he said, "It is by reason that they speak lightly of us." But she said to the damsels, "This gentleman hath saved me from an evil death, and ye do not well to laugh. And an honourable man is he, nor would he do aught worthy of blame." And at that, the minds of the young girls were set at rest, and they said, to her, "Were we in thy place so would we also do." And Abu Zeyd was comforted, knowing that they would keep all things secret.

And the Narrator began to sing :

Saith the hero Abu Zeyd the Hejazi Salame, When I entered the camp and the tribe, and stood in their midst the dwellers,

And the day dawned in the heaven, and my prayer had been repeated,

Then came Alia greeting and bade me a fair morning, And I gave her back the salute, the noble daughter of Jaber. 
And she said again, "Good morrow to thee, O Abu Mukheymer,

How hast thou done us honour, thou noble prince of the great ones!"

And Alia sought the pavilion where the thrones were set in order,

Eighty towards the right and sixty thrones to the leftward,

And fifty more at the front with stuffs embossed with jewels,

For there had Alia placed them. And the drums of joy were beaten.

That the Princes' daughters might hear and come forth at her bidding.

And forth anon came they with trailing robes of saffron, And sat them on the thrones of Agheyli, the noble maidens.

And they asked, "What mean the drums, $\mathrm{O}$ thou our Prince's daughter?

What meaneth thy rejoicing?" and she, "Rejoice, $\mathrm{O}$ Damsels."

And Abu Zeyd the while lay close in the tent hidden. And she bade the fair ones sit, the daughters of the great ones.

And she fetched a throne of gold inlaid with crusts of jewels,

And went to Abu Zeyd and bade him to the assembly. And he reproved her, saying, "Thou art a Prince's daughter; 
Have we not sworn an oath to keep this matter secret? And wilt thou blazon it round with these tonguewagging damsels?

A secret is for two, or four at the most, for keeping. But what and where is it laid bare among a thousand?" And she bade him cease his doubt nor thus mistrust the damsels.

And she led me, and I went shamefaced and in amaze-ment,

The damsels watching near and whispering to each other, With their veils drawn to their faces. And Alia stood. before them,

And with her Abu Zeyd, and she bade me straight be seated.

And she sat down by my side, a wild roe from the desert. And we seemed a bridal pair, on thrones of gold, newwedded,

And we watched the sport and play, the festival of rejoicing.

And the damsels each at each looked and at us, in whispers

Asking, and half aloud, "Who then may be this stranger, A prince? a noble born? a man of race and lineage? Watch well his garments, ye, his bearing, his demeanour, Surely he something hath of king-like in his gesture." And one cried, "Hearken all, and I will read the riddle. This is a holy man, one unacquainted with women, Strange to the wearers of plaits." And another, "Nay, I tell ye, 
And let my word be heard, " This Sheykh is of the great ones,

Else or a wise magician, whom Alia entertaineth For some occult design - that, or a spy and prowler." And Abu Zeyd was aware of these their words and guessings,

And his heart within him sank, and his head dropped, and his tears flowed,

And Alia, when she saw him downcast, "How now, Salame,

Art thou thus faint of heart?" she cried to her sad lover. But he, "The thing hath come of which I feared, $\mathrm{O}$ Lady,

And these light-minded girls make speech of us for evil.

This is a Sheykh, saith one, and that, a spy, a prowler. But know a sherif am I, my grandsire was Mohammed. The truth it is, O Lady, I am of this proud lineage." And she called to them, "Shame on ye, and shame on your suspicions,

Ye daughters of my people, ye fair ones light of fancy. List, I will tell ye all within my oath's prescription, (Yet were a breaker of oaths but cast away to perish) I am the Agheyli's daughter, the noble born, I Alia. And whoso of ye all, ye fair ones, speaketh evil, The same hath done me wrong. And which of ye, $\mathrm{O}$ damsels,

Is of my high condition? And which hath longer hairplaits, 
Or is of darker eyes? And when was I blameworthy? Where is my fault? Nay, truly, were it but yours to. keep it,

My oath should bind ye too. Speak rather in all plainness,

And I will hear ye out, for true words are a precept." And they said, "Thy oath is binding. Thou doest well to keep it,

And to betray were sin, ay, even the seal of perdition. We are thy witness all, thy whole life hath been blameless,

A luminous life and fair, beseeming thy high lineage: Daughter of glorious sires, none might presume to blame thee.

Only we wondered somewhat to see thee with this: stranger,

For thou treatest him as brother, and thee thyself as sister-

And we were astonished thereat, and our minds fell in doubting,

And we talked and questioned still, and argued it together."

But she, "O damsels, hear me. Did ye but know his: merit,

Ye would sell all to possess him, he being of the great. ones,

A prince of noble lineage, a mighty man of valour; This is he, the renowned, who made Helal victorious, Abu Zeyd Salame, the Hejazi, and none other." 
And they answered, "Fear thou nought. We will keep close thy secret,

For that which thou hast done we too had surely done it. We will be to thee in this to the end of thy heart's wishes,

And to him too, to the end. No ear shall learn it of us."

Said the Narrator :

And when the maidens and Alia had made an end of their talking, and they had said to her, "Fear not, we are with thee, and of nothing of our souls will we be niggardly for thy sake, and all that thou hast done that too would we have done; and one such as is this knight were more worthy our possessing than all else in the world, for he is without guile and without blemish; -then Alia, hearing this, her heart was quieted, and she arose full of joy, and bent down and kissed the hands of Abu Zeyd. And all the damsels in like manner kissed his hands. And they undid their veils before him to the right and to the left. And Alia bade them bring meats in dishes, and the damsels brought them. And the servants and they rejoiced and were glad together. And when their meal was ended they brought wine and drank of it, and made merry until night fell on them. And they sang psalms and canticles, and played on instruments of music, nor did they leave their merriment for twenty nights, so that $\mathrm{Abu} Z$ Zeyd forgot his people, and it was to him as to one who had been born among 64 
them, nor cared he for aught that should happen in the land of Helal. But on the twenty and first night he remembered where he was, and how he had come thither, and the story of the ancient dame who had sought him and the pledge he had given her to obtain for her that which she desired. And tears came to his eyes and flowed down upon his beard. And when Alia saw this she arose and asked him why he wept. And he said, "I have been remembering my people, and those that are dear to me afar and the business that I came on." And she said, "Wait only till it be dark." And he waited until the night came. And she arose and fetched the keys and delivered to him the mare. And she brought him change of raiment and a skin of dates and butter and bread. And she said, "Take me also with thee with the mare, and leave me not to suffer blame." And she clung to his stirrup. But he swore an oath to her that he would return and protect her from her father. And she let go the stirrup. And in that guise he left her, and they were both weeping. And Alia turned from him with weeping eyes, and lamented grievously at their parting. And he went his way through the desert, while she remained in her sorrow. And she sat upon the ground with the daughters of the great ones, and they burst forth all in lamentations and tears.

Then singeth again the narrator:

Saith she, the Princess Alia (and the tears flowed from her eyelids), 
" $\mathrm{Ho}$, ye daughters fair of my tribe, to my words give heeding.

Be ye my secret's keepers. This one by his fair actions Hath earned the better part, ay, praises everlasting.

Let every creature praise him, and God him keep, the Creator."

And they said, "We hear and obey, a thousand times obedient,

Our souls shall thy ransom be to hold our lips closeguarded."

And Alia went to him, and his right hand and his left hand

Kissed she, and they too all, while the dark one stood astonished.

And they said, "May God reward thee with good and grace and blessing.

Oh thou Emir Salame, champion among the great ones." And they called to A lia loudly, "Lady, thou daughter of Jaber,

"Bid that the meats be spread, and feast we with this stranger."

And they brought the fruits and the meats, and the dishes meet for Princes.

And when the meal was done then poured they fair potations,

Drinking in jewelled cups with skilled musicians and singers,-

Where should the like be found ?- for they sang in such sweet measure 
That, if a bird had heard, it had stooped from its way in heaven.

In figure and trope they sang, of four-and-twenty stanzas. And Alia chose eight players, the cunningest among them,

Four for the lute and viol, and four for hymns and chauntings.

Each sat him down and played, and they sang with pleasant voices.

Thus twenty nights went by as a single hour in swiftness. And it seemed to me my life had been ever thus from its outset,

Till I forgot Helal, even Helal ibn Amer.

Then suddenly the thought came to me of my people, My tribe and my high place, my friends and war companions,

And tears ran down my face-I did not seek to stay them-

But sat as a man crazed. And Alia, when she saw me,

"What aileth thee, Abu Zeyd, and what may be thy trouble?"

And I said, "O Alia, see me how I thus late remember My glory and my tribe, and friends, and war-companions; See, I have lingered here these twenty nights in number In this thy stranger tribe. And how then shall I end it? Arise and bring the mare, and see that thou delay not, If thou be one of trust." And she, "I will surely bring her, 
And may the merciful God, O Prince, make smooth thy journey.

For truly saith Ibn Arus, 'The dark night brought the prowler."

And I said, "I hear and obey," yet ceased not to be troubled

Until the night should come. But near the hour of sunset

Alia arose and said, "It is time." Then like a lion

Rose I, and roared, "I hear and obey, thou daughter of Jaber."

And Alia threw off her jewels, and she went out and I followed

With a loud-beating heart to the space beyond the tent ropes,

And we walked in the space apart 'twixt Alia's and the mare's tent.

And she held my hand as I went, like a lioness, I like a lion.

And when we had come to that other tent, then she gazelle-like

Stepping passed to the well, and into its depths went Alia.

And presently came again with a goatskin filled with water.

And she took from it the keys, and she opened wide the stable-

For the night was dark-and within we heard the mare's feet stamping, 
Yet stayed she at the sound of her step, the Agheyli's daughter.

And Alia stooped and loosed from the mare her fetters of iron.

And I led her forth in joy, the mare, nor hid my pleasure. And she brought the saddle in haste, and bound it fast with its girthing,

And she hung to it a nosebag as ready for a journey. And I with my hand the while set on her head the bridle. And she stood at the mare's near side, and close behind the saddle.

And she said, "Yet leave the cords, lest they be thy undoing."

And I left them on the ground, cords of the red silk twisted.

And she came beside me near, and held me by the fingers,

And said, "O Abu Zeyd, give ear to me and hearken." And she brought me all of the best, and a fair change of raiment,

Garments rare of glory, rejoicing the beholders. And she said, "O Abu Zeyd, leave here thy ancient garments,

And put on these, the new, $\mathrm{O}$ thou illustrious hero." And I named the name of God, and I put on the raiment. And clothed I stood as a King, even as one of the Sultans.

And she brought me too the armour of the Emir Zohane, 
And a sword from the land of Yemen, its blade was sharp and shining,

And girt it to my left side. And I loosed it from its fastening,

And drew the blade from its sheath, and stood like the King of Terrors.

And I went to the grey mare's side, and took her rein in silence

While Alia wept aloud and her tears ran down in streamlets.

And I named the name of God and sprang into the saddle,

And touched the mare with my heel. But Alia still delaying

Put in my hand a spear (its point would split a pebble, And it shone in the night like a star) and I bore it on my shoulder,

And my heart leapt high with valour, and I longed to meet the tribesmen

And charge them one and all, alone, I without helper. And fain was I they should wake that I might give them battle,

And drive them with my sword, their mightiest men of valour.

And she brought me dates in a skin, and made me all provision.

And thus was I. And she, still clinging to my stirrup, Cried, "Let me go with thee, astride the mare, behind thee. 
Let me be with thee still while he my father liveth." But I said, "Nay, yet I swear thou shalt not be forsaken, Nor will I seek Helal till first I come back for thee, Having devised a plan." Then drew I away my stirrup, And the tears ran down my face, and my heart was grieved within me.

And I went forth on my way and heard her still lamenting, Even as I rode afar. For she cried on, "O Salame, Haste thee back, for thy going is as a fire that burneth." And she turned to the pavilion, and sat down on the carpet,

The carpet of amber silk. And, "Where is he, Salame?" She cried to the pavilion. "If he come not back to seek me,

Lo will burn thy hangings and tear the hair thy covering. If he cometh not, Salame, a tomb shall be my dwelling. And yet the time shall be we shall both meet together: For this be praise to God the Lord God the Almighty. And I ask my pardon of God for all sins and transgressions,

Him who is my protector in the high Heaven of Heavens.'

Said the narrator:

And when the Emir Abu Zeyd had departed with the mare, and had taken his leave of the Princess Alia, and had passed into the outer pastures, then remained the Princess a long while weeping at his going, and in doubt how she should meet her people, and in fear of 
what might come to her through the stealing of the mare. And she returned to her tent, and threw herself upon her bed, weeping with both eyes. This for her. But as to the Emir Abu Zeyd, he too fell adoubting as he rode; and he said, "If I go back now to the Arabs, mine own people, and to my business, nor take thought of Alia, it will certainly happen that our doings will be made known, and her father will slay her; and, on the other hand, if I should return to her, it will be a matter of long duration, and I shall be a great while withheld from my people and my affairs. Now, therefore, it were better I should go see that which is happening among them." And he stopped at a fountain of water, and he drank of it, and he gave his mare to drink. And he sat him down to think over all his plan, and he remembered the day of judgment, and the oath that he had taken to Alia that he would return to her before going to his own people. And this is what happened in the case of the Emir Abu Zeyd.

And at this point the Narrator began once more to sing, and it was in the following verses:

So did my thought return to the Helali Salame,

When he took with him the mare, and set him to do his With all that him befell, O men, among the great ones. The grooms of the mare went in to the grey mare to groom her,

Entered within her tent, and found a lantern burning, 
Yet found they not the mare, nor token of her presence. And they fell in consternation, $O$ people, and much doubting.

And they cried, "Alack-a-day! To our help, $\mathrm{O}$ men, O warriors!

The grey mare of the King is not. Ho, ye of courage, Go with the news straightway. Tell the Agheyli Jaber." And a tumult vast arose in all the neighbouring campfires.

And the Emir Fadel came, confused with the much shouting;

And he called to them aloud, " $O$ warriors, wherefore shout ye,

Casting the camps in fear, as though the foe were on ye?"

And they brought him a kassás, a cunning man, a tracker,

One learned in all signs, that he might search the desert. And lo the footsteps ended at the tent of Alia.

Then were there wondering looks among the camel riders,

And a thousand horsemen rode, Fulano and Fulano, Every name of worth, a gallant band of fighters.

And the hero Abu Zeyd lifted his eyes, and saw them, Like locusts on the plain. And he tightened his mare's girthing,

And called aloud to all, "Come on, if ye have courage." And they gathered near and near, and the dust of their hard riders 
Rose like a cloud to heaven. And presently they saw him,

And he could see their eyes, and the flashing of their spear-points.

And the foemen called aloud, " $O$ thou of the race of Himyar,

Thou shalt not flee our wrath, not though thy back grew pinions.

For he thy sire of old came thus. And thou, what wouldst thou?"

And to them Abu Zeyd, "My right lies in my spearpoint.

Wait rather, all of ye, that I may prove your boasting." And I charged, said Abu Zeyd, and lo I was among them.

And the din of battle rose, and the clanking of the sword-blades,

And I could not count their numbers spread on the plain like locusts.

Roaring they came on me with the loud voice of lions. You had said a cloud in heaven struck by the bolts of thunder.

And to my soul I said, "O thou Helali Salame, To fly were shame on thee. Nay, rather fear thou Alia, Lest she should send for news how thy back turned in battle."

And I saw my death by the spear as the best of doubtful issues.

"Death is better than talk," I said, "the words of the idle, 74 
Ay, than the words of disgrace. So go I to destruction, Nay, though I win to my tomb in the day of evil fortune."

And I turned my mare and sprang, like a lion in the seizing,

And I pressed her flank with my heel and sent her flying forward,

And I charged home on their ranks, nor thought of wound nor danger.

And I smote them with my sword till the air shone with smiting.

And I met them once and twice with stark blows homeward driven.

And they pressed me left and right as the high banks of a river,

Even the River Nile in the full day of its flooding, And the whirlpools sweep with might and overwhelm the bridges.

Twenty foes and five fell down before me smitten, Nor cared I them to slay, being of Alia's kindred, But tumbled them on the ground with sharp taste of my spear-point.

And they turned back in confusion, each man to his own dwelling,

While I pursued them still as the King Death pursueth. And I pricked them with my spear from the first third to the latest.

And they stopped, and charged, and rallied the while I pressed and smote them. 
And I saw again their eyes, and again they pressed me sorely,

Till I put my care on the Lord, the Lord God the Creator,

And all my load on him, the Prophet, the Muhajer. And I feared-they were so many-lest they should take or slay me,

Yet trusted I the Lord, who is a Lord of mercy.

But about the hour of the Doha there came at me a horseman,

And he cried out, "I am he, the son of Agheyli Jaber, Suliman men me call, the bravest of the bravest."

And he shouted to me, "O slave, is it thou, thou thief of horseflesh?

Thou who smitest our people, and makest naught of our great ones?

Show us here thy courage. Get thee to the fight, thou dark one."

And I charged on him like a lion, a lion roused to the seizing,

And before my wrath he fled, nor found I one to withstand me.

Nor stayed he of his running till at the tents of the women,

Even the tent of Alia-hers with the plaited tresses. And I pressed him close behind, and drove him to the tent ropes,

And Alia came out, crying, "May the great God thee succour,

$$
76
$$


Even as $\mathrm{He}$ succoured $\mathrm{Him}$ who fled to the noble: city.

Fight thou on in all heart, nor fear the sons of the Arabs, $\mathrm{O}$ thou worthy of praise, for these Agheylat are boasters. Fight with the whole of Agheyl, O thou redoubtable hero."

And when they heard her words, the horsemen stayed in their running,

And seemed to take new thought in council with their great ones,

And at her railings stopped and looked at one another; And each to the other said, "She knoweth, then, this champion.

Hers is the fault of the mare, the grey mare of our chieftain,

Hers the treachery is. What further need we trouble, Spending ourselves in vain, with treachery behind us? Rather return we straight, and tell the Agheyli Jaber Of the goings on in the camp, and that which was in his. dwelling."

And they turned to the Emir Fadel, the Prince, the Agheyli.

And he asked them, "Saw ye aught of the enemy of our people ?"

And they said, "Ay, saw we him thine own grey mare bestriding,

And he turned on us as a lion, a lion roused to the: seizing,

Dark-hued, beautiful-faced, and nob'e in his anger. 
And he drew his blade on us all, as it were the flash of the lightning.

Many were we, he one, nor was there any beside him.

Much we wondered to see him thus, O worthy of honour! One alone he fought with us all, nor had he a helper. And he drove us back from the field, our horse and camel riders,

$\mathrm{He}$ on the mare thou knowest, and following close behind us.

Thus we came to the camp, we first, and then the stragglers,

All of us fighting the hero, and no man looked to his fellow.

And so till the sun was high and the day rose to the Doha.

Then came thy son to our help, and he too fled from the fierce one,

Fled with a doubting heart, sore struck, to the tent of Alia.

And Alia, seeing this thing, came forth beyond the tent ropes,

And called aloud to the foe, and prayed for his more glory.

And little account made she of the trouble of her people. Yet succoured she thy son. Though he, the adversary, Is all the thing of her care, nor careth she for another. And when this case stood clear, then said we each to other, 
'Alia the stranger knoweth, the grey mare she hath given.

Hers the treachery is, thy daughter's, Agheyli Jaber.' Therefore left we the foe, and came we here before thee. Laying thee bare our case. And this is our tale and story.

And what hath been to the mare is clear to all the people."

Said the Narrator :

And when the Agheyli Jaber heard this talk he was overcome with trouble, and it seemed as though his understanding had flown from him and his senses. And he said, "Bring Alia before me." And they made haste and went to her, and bade her, "Go, for thy father calleth thee." And she obeyed, and went with them before her father. And he said, "O wicked one, what is this that I learn of thee and thy deceits, and that thou art the reason of the loss of our mare, and that thou didst call down a blessing of victory on our foeman when he had wounded thy brother Sulyman, and that thou gavest him in ransom and all our people for that other?" And she said to him, "Yea verily, for I know this enemy, and it is I that gave to him the mare; and wert thou acquainted with his worth, thou wouldst surely give him (and it would be a pleasure to thee) all thy wealth and thy possessions and everything that thou hast." But when he heard these words of her, the matter appeared to him still more of moment. And he called on those near him to bind the girl by the shoulders, and to bring 
wood and lighted coals to burn her withal, that she might presently taste of the cup of death. And at his word they fell upon her, and bound her; and they kindled a fire, and brought her to it, and it remained only that they should cast her thereon. And Alia beheld this that was prepared for her, and her heart fainted with fear.

This, then, is what happened to Alia, and between her and her father. And the Narrator once more singeth :

Lament the men of Agheyl, the men of Helal ibn Amer : Lo, there is nought of good in the world, and nought of pleasure,

If that children deceive their sires, and be of the wicked. And, as they talked, behold a wise man spoke to Fadel : r Lo, the thing thy daughter hath done is known to the people,

Yet is the cause of it hid. Now therefore send for thy daughter,

That thou mayest know thy foeman. Let her his name discover,

Since that she knoweth him thus, and thou shalt find assuagement."

And Fadel heard him speak, and all his wrath was kindled,

And his mind was shaken sore, and his soul set in confusion.

Yet sent he forth for Alia, and bade her appear before him. 
And they brought the girl to his tent, and she came to the assembly.

And he said, "What dost thou, my daughter, and what are these thy dealings,

That thou betrayest thy tribe? Thou art a shame to the Arabs.

They say thou knowest this man, this enemy of thy people,

Ay, and didst give him the mare. Thus speak of thee the great ones."

And she answered, "Yes and yes. I know him, the adversary,

And gave him, too, the mare; nor do I seek to deny it." And Fadel's wrath grew hot, for now her guilt was proven.

And he bade them bind her fast, and bring the wood for the kindling.

And even so did they. And they bound her right and her left hand,

And they heaped the wood, O people, even in their hour of anger,

And they set a spark to the heap, even in the midst of the desert.

And Alia's eyes beheld, yet bore she her fear in patience, Nor spoke she any word, nor gave reins to her terror.

\section{Said the Narrator :}

And when they had lit the fire, while Alia watched the kindling, behold, her fear was great, and her eyes looked 8 I 
to the right and to the left hand, because that Abu Zeyd had promised her that he would return to the camp; and while she was in this wise, suddenly she saw $\mathrm{Abu}$ Zeyd standing in the midst of the Arabs who were around her. And he was in disguisement as a dervish, or one of those who ask alms. And he saw that she was about to speak. But he signed to her that she should be silent : as it were he would say, "Fear not, for I am here." And when she was sure that it was indeed he Abu Zeyd and none other, then smiled she on him very sweetly, and said, "Thine be the victory, and I will be thy ransom. Nor shall thy enemies prevail against thee." But he answered with a sign, "Of a surety thou shalt see somewhat that shall astonish thee." And this he said as the flames of the fire broke forth.

Now the cause of the coming of Abu Zeyd to the place was in this wise. After that he had gone away, and had taken with him the mare, and that his mind had entered into its perplexity as to what might befall Alia from her father, lest he should seize on her and inquire what had happened, and why she had cared nothing for her own people or for her wounded brother, and why she had cried to Abu Zeyd, then said he to himself, "Of a surety I must return to her, and ascertain the event." And looking about him, he made discovery of a cave known as yet to no man, and he placed in it the mare, and gathered grass for her, and closed the door of the cave with stones. Then clothing himself as a Dervish, he made his plan how he should return to the tents of 82 
Agheyl. And forthwith he found Alia in the straits already told, and he made his thought known to her by signs, and by signs she gave him to understand her answers.

And at this point the Narrator began again to sing, and it was in the following verses:

So returneth my tale to the Hejazi Salame,

The hero Abu Zeyd, bearer of all men's burthens,

When that these had returned, the foemen from their fighting,

And she of the jewels had called aloud on his head a blessing,

Then came back the hero Salame, he grieving for Alia, Much in pain came he, and pondering his black fortune. And to himself he said, "O thou, Hejazi Salame,

Wilt thou return to thy people, or wilt thou return to Alia?

I have reckoned the hour of judgment, and made account of its terrors,

When all is meted to men, the good with the evil dealing:"

And I counsel took with myself how I should turn me towards her,

And learn the truth of her way, and how it sped with her fortune.

And I feared lest evil men should stir the anger of Fadel,

And pain should be her lot, and grief in the day of evil. 
Yet was my mind distraught for the mare, how I might dispose her,

Till of a secret cave I thought, deep dug in the mountains,

And there I placed her close, and grass I brought her and water,

And gathered stones from the hill, and sealed the cavern with boulders,

Troubled in mind, $\mathrm{O}$ people, and left her there, and departed,

Uttering verses of power to hide it from eyes curious. And thus I eased my grief, and soothed my soul in its anguish.

And I passed on foot through the waste by the ways my steps had trodden.

And I sat alone with myself in the empty breadth of the desert,

And I took from my back my wallet, and shook the dust from its leather,

And loosed the buttons all, and searched its inner recesses,

And took from it a dress should serve me for disguisement,

Unguents and oil of salgham, and red beans and essalkam,

And I roasted them on the fire till they were ripe and ruddy.

And I whitened my beard with chalk, and pulled down my mustachios, 
And dyed my face with saffron till my cheeks glowed like apples;

And I wrinkled the skin of my brows and crooked my back like a bent bow,

And leaned upon my staff. For am I not, O people, A man of infinite wiles, a cunning man, a deceiver?

And over the rest of my clothes I set the garb of a dervish,

And held a pot in my hand, even of the pots of the beggars.

And thus in my disguisement I sought his tents, the Agheyli,

Troubled still in my heart for Alia and her trouble,

Nor ceased I to walk and run till I came to the tents of

Jaber,

And found there Alia bound, with wood made red for the kindling.

And she cried, "Alackaday! for the men of evil dealing. Call I to God above, the God of power and compassion,

Him whom no eye may see, to hasten back the dark one.

$\mathrm{Ho}$, in what place are thy eyes, thou foolish man, Salame,

That thou comest not to her help from these which stand around her?

Why dost thou leave her to these, the insolent men of evil ?

What didst thou say, O Abu Zeyd, when forth thou wentest? 
Or was thy talk a deceit to her, O Abu Mukheymer? Wert thou false and untrue, $\mathrm{O}$ beautiful one, $\mathrm{O}$ hero? If that thy speech were truth, then come thou to her succour."

And I called to her with a sign, "Nay, be not wrath in thy anger;

Only the foolish are wrath." And she answered with a gesture,

"Victory be to thee, O Prince, and a life of glory; Mayest thou still of thy foes the snares outwit, the deceptions.

Lo, my soul is a ransom for thine, and love I this anguish

So but I know thee true, and minded not to betrayal." And I called to her with a sign, for we needed not more language:

"Traitors and evil men shall have their payment of evil. Fear not, for I am here, and, not though the fire be kindled,

Be thou disturbed in mind, for lo, I stand at thy right hand;

And when the flames shall rise, then look for thy deliverance."

Thus did I comfort her grief. " God make thee," she said, " victorious."

Said the Narrator:

And when Alia perceived the Emir Abu Zeyd, and when he had made himself known to her, and they had 86 
spoken each by signs to the other, so that her heart was quieted, and her mind lightened of its fear, then Abu Zeyd left her, and went on further a short space, until he came to where a holy man stood up in prayer. And he stood up with him, and made his recitation, until the assembly was at an end. And the fire was ready kindled, and they brought Alia towards it, and they were about to place her thereon, when the Emir Abu Zeyd came near to Alia, and set aside the people who were pressing round her, and stooped down towards the fire, and having called in a loud voice upon the Prophet, he beat out the fire until it was extinguished. Then went he back to Alia and loosened her bonds, the people the while standing silent in wonder at his doing. And presently they went to the Emir Fadel and told him of what had been. And the Emir said, "Let him even do as he is minded and as it pleaseth him, for it is not meet I should set myself against any doing whatsoever of an holy man. And for the holy man's sake will I grant Alia her forgiveness. And tell her to return to her own place. But for myself need is that I go forward to greet him." And the Emir Fadel arose quickly and approached the fakir, and he kissed his hand and said to him, "O my Lord, there hath befallen me a great and redoubtable ill-fortune. Make thou thy prayer for me to our Lord that $\mathrm{He}$ give me back my mare; for is $\mathrm{He}$ not the giver? And, if that thou shouldst desire to remain with us, surely there shall be to thee a fair welcome ; and, shouldst thou die in this country, be assured 
we will make to thee a fair sepulchre whither at all hours will we come both of the night and of the day." And when Abu Zeyd heard him say this he answered him, "Of a surety this matter shall be made clear to thee and thou shalt know the truth and behold it with thine own eyes." Then the Emir Fadel took the fakir with him, and he made Abu Zeyd to sit in the seat of honour; nor said he aught further nor spoke more of that which had happened on the yesterday nor of the matter of the mare.

And the narrator began again to sing in the following verses; and he said :

Now doth my tale return to the hero Hejazi Salame : When that Abu Zeyd had seen the sorrow of Alia, And had said, "O Alia, trust me, trust me and be thou patient,

Swift will I bring thee succour in the sight of all beholders,'

Then went I for a space to the place of recitation,

The place of fakirs in prayer, of holy men who were chaunting.

And I found a man of God in his prayer, O people, enraptured,

And around him many more who prayed in the assembly. And I said to myself, "O Abu Zeyd Hejazi Salame, Go thou down unto these, so shalt thou win a blessing." And I went down to the throng and joined in the recitings, 
And stood as one of themselves, as one of those that are holy,

I who had stolen the mare, even I to chaunt among them,

And all the while my heart was as iron heated for Alia, While we recited aloud from the most noble Koran. And when we had prayed we returned. And the princess was in danger,

For the people had led her forth to where the fire was enkindled,

And right and left she looked if any should come with succour.

Then sprang I to her side like a lion roused in his anger,

And I took her by the hand, while the crowd beheld in wonder.

And I thrust them back with my hands and stood beside the burning,

Committing my cause to Him, the Lord God, the Almighty,

And I cried out, "Burn me not, $\mathrm{O}$ fire, nor seek thou to shame me!

Burn not, $\mathrm{O}$ noble fire, nor do thou hurt to my garments, For if thou work me ill, I bear to the Lord my witness, I who am nobly born, a man of illustrious lineage." And I passed out thus through the fire, and by the Lord's permission

The flames died and fell down, and I walked forth from them scathless. 
And I came to the side of Alia, of her with the plaited tresses,

And I undid her bonds while all the world beheld us: And they said, "He is a Sheykh, a holy man of wonder." And I said to Alia, "See, in what plight do I find thee! I have returned to thee who gavest me my asking. And lo, the flames of fire beneath thy feet extinguished. And my heart is sore for thee, and dazed my understanding:

Fearful am I for thee for sake of these thy kinsmen; For thee would I destroy them with the sword's edge for ever."

But when the people saw-as all men saw-my doings, Then came they to my side and kissed they my five fingers,

And they said, "O holy Sheykh, do thou procure a blessing."

And I undid Alia's bonds while all the world beheld us. Then quickly sent they forth to the Emir Agheyli Jaber,

And they said, "There hath come to us a holy man, a Wely,

Long bearded, untrimmed he, one rapt in contemplation, He hath quenched the flames of fire and made an end of the burning,

Loosening Alia's bonds, her's of the many jewels."

And he told them, "Let him be, I have no mind to oppose him,

Being of the fakirs." - And he the Sheykh came to me 90 
Barefooted, with respect, and shoeless kissed my fingers. And he bade me welcome, nobly, even to eighty welcomes.

And he said, "I guess thy worth, and I will do thee honour ;

My heart is with the fakirs, I seek them night and morning,

And I would pardon Alia were it to do thee pleasure. Yet see, one grief is mine, one all consuming sorrow, O Sheykh, 'tis she, my mare, the fair mare which I rode on ;

Glorious she was to see, the envy of beholders, Light-footed-she is gone-you might say a bird's in its flying.

Yet are her footsteps known to thee, thou master of wisdom."

And Abu Zeyd made answer, "In the day of hasty judgment

The eyes of men are blind; wait rather till the morrow, So shall the truth be seen, and thou rejoice, O Jaber." And he said to him, "O Sheykh, if thou wilt do me pleasure,

Lodge with me here to-night, and wouldst thou tarry longer

A dweller in our land, behold each night and morning To thee shall be of the best the meat that thou desirest, Garments of amber silk (and all good things in order), And if that Death should thee o'ertake within our dwelling, 
Lo, I will build for thee a monument of honour, And yearly make for thee a feast and celebration, And brave men at thy tomb shall keep thee in remembrance."

And the Emir Agheyli Jaber took by the hand Salame, And brought him to his tent and set him with the great ones.

And the people pressed around as it were in the market of Amer,

And with them the fakir, until the dawn was breaking, While still they chaunted on, and thus to the full morning, With song and recitation and noble wealth of feasting.

Said the narrator:

And when they had made the morning prayer, talking and reciting, and $\mathrm{Abu}$ Zeyd with them in great delight, then to them came a swift horseman, and his name was Bedr ibn Saleh er Ramal, the sand-diviner, and he came from the land of Bagdad, a knower of things hidden. And when he had alighted he sat him down with the Arabs, and the Agheyli Jaber saluted him with a fair salutation, and the man said, "O Prince of the people, the news hath reached me of the loss of thy mare, nor have I come to thee save for her sake and to discourse to thee of her welfare if thou shouldst desire it." And the Emir said to him, "If thine be an honest business, the time favoureth." And the Ramal struck the sand and made on it his figure fairly, and he said, "Know that he who stole the mare hath set her in a desert place, and he then came 
back to thee, and is now with thee beholding all thou doest, and hearing all thou sayest." But Fadel el Agheyli said to him, "There be no strangers here save only this Sheykh and thee, thou man of contemplation." Then the Emir Abu Zeyd went to the diviner and he said, "Know that the sand is at all times forbidden, as is spoken by the Prophet, even though the diviners should speak sooth, 'take them as liars.' If, therefore, thou hast other knowledge than by the sand make it known to all here." And the diviner said, "Nay, that should be for thee rather." And he commanded that they should bring him a stone vessel, and wine, and oil, and honey and milk, and roasted flesh, a little of each. And they brought him all that he desired. Then he took from his wallet an image of gold with names inscribed thereon, and the names were names of wonder, and the image was in the form of a son of Adam. And he placed the image in the vessel and poured on it the wine and the oil, and the honey and the milk, and all those things of which we have spoken, and he made invocations with incense, and a smoke rose. And there came to him of the Jinns crowding around him. And the image began to speak to and salute the Arabs, and tell them the story which had been told by the sand. And he said, "Know that none other hath taken the mare, save only he who is called Abu Zeyd Helali Salame, and he is with you in this place." And upon this the Emir sought through all the crowd, but found no man a stranger there save only Abu Zeyd and the 
man of contemplation. And upon this the Emir Fadel shouted to the tribesmen, and bade them "Seize hold of the two, and put them in fetters and take them to Alia, who may haply recognize the wrongdoer, and give us news of the truth of the matter." And they did all that he bade them, and they went into the presence of Alia, and showed to her Abu Zeyd. And when she saw the Emir Abu Zeyd, she made shift to speak to him by signs. And she said, "If thou hadst obeyed me and gotten thee hence home, it had been better for thee than now." But he said, "Fear not, for thou shalt see that of me which shall astonish thee." And he began to recite, and rejoicing quoted verses from the book, and leaping strenuously upward burst the chains that bound him, and it seemed as though he were light as the cotton-seed which floateth in the air. And he took the chains in his hands, and broke them to pieces from his neck and wrists and ancles. And when the tribesmen saw this they went to the Emir Fadel and told him all that had happened. And he said to them, "Not for my own pleasure did I this thing, but being over-persuaded by the diviner. Bring therefore the Sheykh to me that I may beg pardon of him, but take ye the diviner, and place him in his stead in irons. And burn him with fire, and be careful that ye leave him not alive."

\section{Said the Narrator :}

And upon this they obeyed and went to Bedr ibn Saleh that they might bind him. But he said to them : 
"O warriors, have patience until the Sheykh shall be here, and I will then show you the mare and the reason of all. And if I show you not the mare then do with me as ye list." And they consented to his wish. Then brought they to him the Emir Abu Zeyd, and they said to Bedr, "Now is the time for thee to perform thy, word, and let us see how thou wilt fare in the business." And he answered them; "I hear and obey." Then again he took forth the image, and he began to inquire of it what should be.

And the Narrator once more singeth:

Now doth my song return to the Emir Agheyli Fadel, The while he sat with his tribe at the forenoon hour, the Doha,

And around him stood his people, his mighty men of valour.

In pleasant talk sat they, and brave discourse of heroes, Until one came to the camp Bedr ibn Saleh the cunning, Skilled in the sand, a man of power and favoured of fortune,

Bred in youth at Bagdad, his father slain by the spearpoints,

Even the spears of Nathahir, and he an orphan among them.

And when the tribesmen saw him, "Good luck," said they "attendeth."

And they cried "Salaam aleyk, O Bedr, searcher of secrets." 
And Fadel too saluted, even the Emir Agheyli. And he said, "I have come, O Sultan, in doubt of the grey mare's fortune,

Therefore I came from afar, from the lands of the sun's rising,

Seeking to serve thy need though I journeyed west to the ocean,

Or, if she eastwards be, to the furthest tribes of the Orient."

And Fadel answered fairly, "Thou cheerest me with thy coming,

And this one too saith sooth, being a searcher of secrets, For he told me yesternight of thy coming and thy fortune, And the news that thou would'st bring." And to Abu Zeyd Salame

He said, "Thou speakest sooth, for lo, this sand diviner

The like to him is not for the sand's signs and fortunes." And Fadel called to Bedr, "Behold me and my trouble.

I will reward thee well." And he said, "I hear in obedience."

Then drew he of the grey mare a horoscope and figure, And he saw within the lines a semblance in reversal. "An archer leadeth the mare, in the black night doth he hide her,

Guised as a holy man, a man of contemplation, And he is here with you and the name of him Salame, Hidden among you all, to Agheyl a threat and a danger." 96 
And he turned to Abu Zeyd, "O Sheykh, give ear and hearken."

And Abu Zeyd took up the word and gave God praises:

"The sand is sand," said he, "but further hast thou nothing?

If thou hast ought beside leave it no longer hidden."

But when the diviner heard this word, his ire was kindled :

"The sand," he said, "O Prince, hath spoken all things truly,

It hath made known the sooth and shown the grey mare's robber ;

Behold he sitteth here, one of the crowd around thee, And the mare's self in a cave close shut behind thee lieth.

This is a certain truth. Praise be to God the knower. Yet shall it plainer speak, so thou, $O$ son of the great ones,

Give but the word they bring stone jars with wine and honey,

All that thou canst procure, with milk and meat and butter."

And they brought him all he desired, and he took from his bag an image,

An image made of gold, with talismans and figures, Made in the likeness of man, with legs and arms and shoulders,

And on its hand a ring, a seal-ring set with jewels. 
And he made the image stand in the vessel, and poured upon it

Of wine and milk and honey, regarding it intently. And he covered it with a lid, and set coals in a censer, And threw thereon of incense and fragrant wood and rosin,

And spake words of enchantment, and called as if entreating.

And there came to him the Red One with a sound of broken thunder,

Jarish, king of the Jinns, encompassed with his whirlwind,

And the Princes of the Jinns in their cohorts and their legions.

And a cry rose from the jar, and the image moved within it.

And the Arabs beheld these things. And he breathed above the image,

And made signs with a wand. And he called aloud to the image,

Saying, " $O$ image, hear me, and sooth be in thy sayings.

Who was it robbed the mare and rode her forth in the night time?

Nay, if thou tell me not, I will cast thee to the people." And the image moved in the jar and rose aloft in the vessel,

And called aloud to the crowd, "To all men salutation, And salutation to him, ibn Saleh, the obedient, $9^{8}$ 
Him who hath sworn by the Name the Compeller of all secrets.

And salutation to Fadel, the prince of Agheyl, the chieftain.

Hearken to me, ye great ones. Give ear to me, $\mathrm{O}$ Fadel.

Strange is the tale of thy mare-ay, write it in thy ledgers-

For he who robbed her from thee is with thee here in Council."

And when the Emir had heard, then turned he rightwards and leftwards,

Looking around in his pride like a pawn made queen on a chess-board,

Yet saw he none but the Sheykh and the man of contemplation.

They alone, these two, stood strange among the tribesmen.

And he called aloud to the Arabs, and bade them bind them in irons,

And lead them straight to Alia, to her of the plaited tresses. -

"For she," he said, "shall know and tell us of our foeman."

And they took and bound Salame and the man of contemplation,

And they ringed their necks with iron and brought them bound to Alia,

Crying aloud, "Behold the offenders of the great ones." 
And Alia rose and came, and straightway saw Salame, And her spirit fell in trouble, and she wept at what had fallen.

And she let him know by signs known only to the dark one :

"Have I not wished thee good, and victory o'er my tribesmen,

When that we sat by the fire? Why didst thou not obey me

When I bade thee straight begone? for lo, the grief, the trouble!

Alas for thee, my people! alas for thee, Salame!

Would that my eyes had seen it not, this day of sorrow."

But he answered her with signs- "Nay, but much speech is foolish.

Rail not at fortune's hand, since all, even my abasement,

Is by permission of Him who knoweth the heart's secrets.

Yet will I show thee a thing shall be to thee a wonder,

Only do thou have patience, and wait on heaven's justice. And the hero, Abu Zeyd, vowed vows and chaunted verses,

And the chains fell from his hands, as it were in handfuls of cotton.

Which when the Arabs saw, they told the Agheyli Jaber. 
And they said, "Thou didst obey this sayer of sooth, this Bedr,

And so did also we, since clear it was thy bidding.

Yet what things we have seen, $O$ Prince, what mighty wonders!

For we saw the chains from his neck fall down, and the fetters sundered,

As the cotton flies in the wind, when the light wind sends it driven.

And now for ourselves we fear lest his wrath for us be kindled.

Think of the day of account." But Fadel, "As God pleaseth!

I flout not the fakir, nor set myself with the stiff-necked.

Rather take ye this other, this sayer of sooths untimely, Boaster and cheat is he. Nay, cast him straightway in fetters,

And bring to me the Sheykh, that I may crave his pardon."

So they went forth for the man, the sayer of sooths untimely,

And seized and bound him with bonds. But Bedr aloud protested,

"Do not this deed, oh men, and be not ill in your. dealings.

Yet were it well, O Prince, thou shouldst ask of the Sheykh his pardon,

Make him a place at thy side. And I will reveal thee all things, 
And show thee of the mare, and tell thee sooth of the Wely."

And when Fadel heard these words he bade them again to bring him,

Saying "Mayhap he will spare, and so my mind find comfort."

And they went again and returned and brought with them Salame;

And the holy man they brought, the man of contemplation.

And to him the Agheyli rose and joyfully embraced him: Barefoot he stood and kissed his hands, the in and the outside.

And he said, "O Sheykh, thy pardon I ask for that which I did thee;

See, I have borne much grief, do thou forbear with my dealings,

Grief on account of the mare and desolation of spirit; And, when that the image spoke, I did thee a thing unseemly,

Yet, oh, the gracious dealing of him that pardoneth sinners!"

And Abu Zeyd assented, "Ay, truly do I forgive thee." And he made him sit by his side. And Jaber bade them loosen

The chains of the holy man. And they sat, they three together,

Making cheer and rejoicing. And all the sons of the Arabs 
Called to them, "Pray, O Sheykhs, we too have grace and fortune,

Since of a truth we perceive that ye are the men of wonder."

Said the Narrator:

And when the Sheykh had come, and the man of contemplation, and the soothsayer, and the sons of the great ones, and there had been prepared for them places in the tent, then Fadel the Agheyli turned to the soothsayer, and he said to him, "Now is the hour come for thee to show thy skill and to speak plainly, and if thou dost not speak sooth then will I slay thee and overwhelm thee with destruction." But the soothsayer said, "I hear and obey." Then went he once more to his image and began to upbraid it with angry words, and he swore great oaths over it, and said to it, "Verily it was no treaty I made with thee that thou shouldest lie." And the image began again to move and to speak to Fadel and to those around him, and to tell the tale once more from the beginning, both that which was without and that which was within. And it said, "O Fadel, how hath the Prince Abu Zeyd saved thy daughter from that'traitor and hath slain Sahel and Zohwa for her sake, and how did she then help him to obtain thy mare and to gain that which he desired of thee! For his is a wondrous case, and the circumstances of it how strange!" And in making an end of speaking it said, "But if thou wouldst hearken to my bidding, then wouldst thou make fellowship and friend- 
ship with him, and wouldst listen to his words and wouldst follow his counsel, nor be his adversary for ever. For to thee he were the truest of companions and of helpers. And he were of more advantage to thee than all the tribes, even than thine own Arabs."

\section{Said the Narrator :}

And when the Emir Fadel heard these words of the image, then cried he with a loud voice, and his cry filled the assembly and all the tribes heard it, and he swore a great oath and said, "Yea, verily will I, though he be the first of my foemen, that $\mathrm{Abu} Z$ Zeyd the Helali, the valiant one in fight, who slew my brethren and my kinsmen and my people." And when he swore that oath, the Prince Abu Zeyd started to his feet and cried with a loud cry which filled the whole assembly: "I am here, even I Salame." And he recited again the tale from the beginning, and all men heard and listened to the manner of his verses. And the Emir Fadel arose and pressed him to his heart, and all his trouble passed from him, and the tribesmen rejoiced at that which had come about. And thereupon the Narrator began to sing and he said:

Now returneth my tale and my singing and my verses To that which him befell the Emir Agheyli Jaber. For when they had sat them down, the chiefs in the pavilion,

And Abu Zeyd with them, and Fadel and ibn Saleh : 
"Act," said he, "by thy word, if thou art a man of knowledge,

But if thou doest it not, know well that I shall slay thee."

And the soothsayer cried, "Ay truly, to all be there rejoicing."

And he turned him to the image with words like trickling honey,

And he struck the jar with his wand and he called aloud to the image,

"Wilt thou be proved a liar? And what is this thou doest?

Long have we been together, and now thou wouldst me evil

Shame and a bitter fortune in face of these the great ones?

All thy life wert thou true to me, nor didst thou deceive me.

Marvel it were to-day if thou shouldst be proved a traitor,

Working thus for my death to bring me evil fortune.

What have I done that thou thus shouldst stir their hatred against me?

Tell me rather the truth of the mare of Agheyli Jaber, So shall his rage be stilled and he bring me forth with honour.

But if thou tellest it not with my hand will I destroy thee, 
And cast thee forth to the flames to be a fuel for burning.

Resolved am I on this, so be not thou of the stiffnecked.

By this and by that I swear, even by the valley of Barhut."

And the image rose in its place, and it called out clear to the people,

"Peace be to ye, O people, and peace to Agheyli Jaber.

Listen awhile, $\mathrm{O}$ Fadel. The tale of thy mare is a wonder.

This was its cause and reason,-the ancient Lady Ghanimeh,

She the mother of Amer, who went to the Helali.

She came in the early morn, and found them sitting in council,

Appealed to Selame's honour, his, Abu Zeyd the Hejazi,

His the lion, the dealer of blows, of wrongs the avenger. She asked of him the grey mare, and he vowed to do her bidding,

Promised before them all, the great ones there with the least ones.

And they heard him speak. And to him is life less dear than honour.

And she said she would wait his coming with the mare, among the camp-fires.

And Abu Zeyd arose and dight him for the journey, I 06 
Mounted his running camel, and went from them a wanderer.

And he cut a road through the void, the empty plains and the mountains,

Till that he reached your land and housed within your dwellings.

Clad as a poet he came and entered in disguisement. And he learned the way of you all, unknown to you, in secret.

And he waited the coming of night till the dark should spread its curtain,

Sitting thus in your midst with beating heart till the night time.

For he is a master of wiles, perplexing with disguisements, -

For whiles as a Syrian he comes, and whiles as a Mogrebbin,

Whiles as from Egypt's land, or a black slave, or from Berber,

Or as a singer of songs from the utmost lands of the Persians.

And the day he came to thy tribe, he slew Sahel ibn Aaf,

Him, O Prince, who is known to men for his deeds of evil.

And with him he slew Zohwa bint Nasser, his companion,

$\mathrm{He}$, the thief of thy mare, protecting thus thy daughter, 
Slaying the traitors twain, and dealing sure destruction. For they were together there for a foul deed in the darkness,

And Abu Zeyd gave ear when they complained of thy doing,

How thou hadst slain his father and seized upon his riches,

And how he desired a vengeance, even on thy daughter Alia.

And when that Zohwa heard him, she said, 'I will bring her to thee.'

And to Alia's tent came she and remained with her the night through,

Talking till well two-thirds of the night were spent in discourses,

And afterwards she said, "And who is this dog of the Arabs?

Is not thy father king, and lord, and sheykh of the Arabs?'

So she went with her through the night, and fate shut fast her eyelids,

And when they were come to the desert, then Sahel, the dog, assailed her,

Seized her strait by the throat, and clutched her necklace of jewels.

And she called to him, 'Nay, spare me.' But he denied her pleadings.

And she cried aloud to her Lord, and made her supplication. 
And when that she had prayed then spake she the name of Salame,

Even of Abu Zeyd, the hero, the right arm of Amer, And at her voice he came and slew those two in the darkness.

And the dark one loosed her bonds and cut her bindings asunder,

And bade her begone to her people and see that none should know it.

And she answered him, 'Nay truly, but first I would know thy lineage.'

And they made an oath together, and they went to the pavilion,

And twenty nights and days were they two there rejoicing."

Thus then spoke the image as though it had seen and heard them.

And lastly the image said, " $O$ prince, $O$ thou of the great ones,

If thou wouldst do my bidding, let there be peace between ye."

Then was the image silent. But Fadel, "God be my witness

That there is peace between us, even though he be the Helali,

Abu Zeyd the destroyer, the enemy of our people.

What though he slew my kin, eight men of them together,

Even eight of my kin, with Zohwa Ibn Talh, and Faher, IO9 
Yet may God give him peace, and may the tribes befriend him."

And Abu Zeyd arose and he spoke to the assembly, And he cried aloud, "Behold me, Abu Zeyd of Helal Ibn Amer,

$I$ in truth was the slayer of these eight men of thy people,

Taking them thus from their joy and dealing them destruction.

And lo, thou art here to-day in the midst of these thy great ones,

And I one man alone. Yet if thou stand indebted,

Take thy due of the lion's blood and all that are with thee.

Now is their time to strike. Let none hold back to spare me."

But Fadel the Agheyli spoke, and thus aloud he addressed him,

"Welcome to thee, $\mathrm{O}$ prince, $\mathrm{O}$ thou the right arm of Amer."

And he rose up and embraced him and made him sit at his right hand,

And Abu Zeyd made known the hiding-place of the grey mare.

And the Arabs pressed around, and the poets sang of his praises.

And the heart of Agheyli was soothed and he cried, " $O$ right arm of Amer, 
Lo, thou shalt have thy wish, though thou ask my soul I will give it."

And this their story is, the true tale of their doings.

Said the Narrator :

And when the image had done speaking and everyone had listened to the story in its completeness, then believed they the words of Bedr ibn Saleh, and their hearts were comforted, and the king welcomed the Emir Abu Zeyd with the fulness of honour, and he showed favour likewise to Bedr, even to the man of contemplation, and all trouble passed from his mind. Then Abu Zeyd made known to them the place of the grey mare and they went forth and took her from the cave and made haste to feast and be merry. And after that, the Emir Fadel remained talking with the Emir Abu Zeyd for seven days, and then Abu Zeyd desired to return to his own country. Then said to him the Emir Fadel, when he had given him noble gifts and with them the mare and slaves, "What wilt thou at my hand ?" And he said to him, "That which I would have of thee is Alia thy daughter." But Fadel answered, "Ay, by the faith of the Arabs, that also is my desire and the extreme of my longings, and moreover thou shalt have with her all else whatsoever thou desirest. And here the Narrator once more singeth :

Now returneth my tale to Fadel the Agheyli Jaber, And with him the hero Salame and all that were there assembled. 
The Arabs beheld ibn Saleh. And lo the Agheyli Jaber

Clothed him with robes of honour and him Abu Zeyd the Helali.

And they bore him a witness of glory, even all the great ones assembled.

And he sat with them seven days a guest new clothed and rejoicing,

And all men brought him gifts, of cloth and embroidered kaftans,

And fifty steeds of the grey, and fifty steeds of the bay ones,

And fifty camels the red, and fifty slaves of the black ones.

But after the seventh day he said to them, "All is ended, I must away on my journey." And Fadel, "As thou willest,

Only return to our joy, and we from afar will meet thee. For 'twixt us brotherhood is, now and to our life's ending,

Thou for a brother to me and I to thee for a brother." And he said, "Be thou clear of evil, thou first of friends and of brothers.

Still is there one thing left, of Alia the espousals, If she should take my hand, then were I with ye, and quickly."

And they answered all and declared "Nay, this were for our rejoicing,

So should ye two remain, twin heroes with us ever." 
Said the Narrator:

And when the Emir Abu Zeyd desired to depart, then said to him the Emir Jaber, "Was it for the mare then that thou camest to our country, or for what else ?" And Abu Zeyd related to him the whole story of the ancient dame and of all that had happened. And the Emir Fadel cried to the grooms, "Lead forth the mare, the Hamameh." And they led her forth and brought her to the Emir Abu Zeyd. And he departed with her after that he had bidden them farewell. And he went back to those shepherds, and took from them his riding camel, and ceased not until he had returned unto his own Arabs. And when they saw him they saluted him, and came around him and rejoiced exceedingly, and they made feastings, and the tribe rejoiced. And Abu Zeyd related to them all that had happened to him, and they wondered greatly and all the tribe with them. Then sent he to the ancient dame Ghanimeh and begged of her that she might come, and when she came he delivered to her the mare and the gifts and bade her depart to her own people. But she said to him, "Nay, but send with me one who shall charge himself with my affairs." And he sent with her Abul Komsan. And Abul Komsan went with Ghanimeh. And they had not journeyed seven days when they met with the tribe of En Naaman. And Abul Komsan went unto Naaman and said to him: "Saith my lord Abu Zeyd to thee, let Amer espouse thy daughter, for behold, the mare thou didst require of him my lord hath obtained her for thee." But when 
Naaman heard that, he said, " Take the mare and return to thy Lord and say he will not listen to thy words, neither will he follow thy counsel." But he said to him, "If thou wilt not do this thing then will I slay thee in the midst of thy Arabs, and destroy thee utterly." But when Naaman heard this he leaped upon his mare and rushed upon Abul Komsan. But Abul Komsan struck him with his spear upon his breast and pierced him through, so that the spear shone beyond him. And he called out to all the men of the tribe, and defied them, saying, "I am your peer, and better than your peer." But they said to him, "Nay, but thou hast done us a service, for this one refused to do according to our counsels." So Abul Komsan bade them bury him. And they buried him. Then he bade them to bring Amer before him, and Abul Komsan made rejoicings for him and placed him upon the seat of authority in the room of his uncle Naaman. And they brought to him also Betina, the daughter of Naaman, and he ordered their marriage. And when he had done all these things he desired to leave them. But they brought him gifts and they led forth for him the mare, and he took her and his leave of them and departed, and returned to his master and told him all the story. And Abu Zeyd. rejoiced and gave thanks.

And the Narrator once more began his singing and he said:

Saith the Agheyli Fadel the hero, "O thou, Helali, $\mathrm{O}$ thou man of descent, explain to me this thy coming. 
Was it for only this, the stealing of my grey mare, Or for some other thing thou lightedst at my dwelling ?" And Abu Zeyd replied, the Hejazi Salame :

"The cause of all was this, the cause of my meeting with Alia;

It was a woman bereaved, a guest of illustrious lineage. Suppliant she came to me, and made request of the grey mare,

Wishing to win a bride. And I went, and all my fortune, Lo, it is known to thee. And this, O prince, is my story." And Fadel called to the grooms, "Lead forth," said he, " the Hamameh,

And girth her back with a saddle, a saddle crusted with jewels."

And they brought her forth in her beauty, the fair gazelle of the desert,

And on her back was a saddle set of silver and jacynths,

And in her mouth a silver bit with gold for her reining, And the reins of woven silk, of silk and nought else woven.

And Abu Zeyd arose and saluted the Agheyli,

And turned and went on his way, and with him slaves of the horsemen.

And thus for seven days, till he came to his own pastures;

And the men of Helal beheld him, even the horsemen of Amer.

And Abu Ali Serhan made straightway a great feasting. I 5 
And the dark one told his tale and all the deeds of his daring.

And he sent for the ancient dame, and handed to her the grey mare,

And with it the gifts and stones, and divers notable treasures.

But she said, "O Abu Zeyd! oh thou most worthy of honour!

Oh thou the beautiful one, may the Lord God grant thee blessing."

And he called to Abul Komsan and bade him attend the lady :

"Go with her straight," said he, "to Naaman, and greet him,

Greet him thus in my name, and all the men that are with him.

Let him deliver the bride to him the son of his brother, And leave with him in her stead the mare of Agheyli Jaber. But if he yield her not and be he of the unwilling, Do thou smite off his head, else is Salame ready. And he said, "May but I do it and may thou live in thy glory."

And Abul Komsan went forth and with him a thousand horsemen,

And they rode for seven days to Naaman and his people. And the slave dismounted with " peace be with ye," and told him his story.

But he laughed aloud and cried, "What of the mare of Jaber, 
Have you the mare in your hand? the grey mare! the Hamameh!'

And Abul Komsan said, "My Lord Abu Zeyd hath brought her;

He hath achieved this thing, and all for the sake of Amer." But Naaman spoke again, "And is Abu Zeyd thy master?

Take thee the mare and begone, and speak to him that hath sent thee;

Know that of Naaman no man yet hath claimed the obedience."

And the slave arose in his wrath, and flung himself in his saddle

And roared aloud like a lion, a lion roused to the seizing,

And for Naaman nought cared he, and nought for them that were with him.

And Naaman called to his people, "Ho ye, the tribesmen of Dagher!

Ho, to my help, O men!" But quick as the lightning flasheth,

Struck the slave with his spear, and the point passed through his body,

Even Naaman's body. And all men fled in confusion. But Abul Komsan cried, "Fear not. Nay, rather together

Go we and bury this dog, for he died an unbeliever." And they went with Abul Komsan and buried him as he bade them. 
And he sent of them for Amer and he sent of them for Betina.

And the wedding feasts were spread and the days went by in rejoicing.

And Amer returned to his people with horses and with camels.

And they said, "O Abul Komsan, lo thou art a man of honour,

For thou hast slain the wicked, and we are thine, the protected,

And thou hast befriended Amer. Do with us as thou desirest."

And he answered them, "O people, peace be with you, O people-

Salame is my lord-to-day and now and for ever."

And Amer brought him the mare and with it gifts and treasures,

And he said, "Thou didst bring this gift. A gift of me thou shalt take her."

So he took the mare at his hand, and the gifts, and he departed;

And when he came to his tribe he told Abu Zeyd thestory. And Abu gave thanks, and this is the end of their telling.

\section{Said the Narrator :}

And when all these things had happened and the Arabs had rejoiced, and the heart of Amer had been quieted, and he had espoused the daughter of his uncle, even Betina, and when Abul Komsan had returned to his 
lord with the gifts and with the grey mare, and Abu Zeyd had asked him of the news and he had told him of that which had happened, then gave Abu Zeyd thanks, and next he bethoughthim of the Princess Alia and of that which had been agreed between them; and he turned to his people and said to them, "I must go to Fadel the Agheyli Jaber." And they consented thereto. So he took of his Arabs two thousand, and they journeyed until they arrived in that country. And when the horsemen of Agheyl saw him they gave him the salute of peace, and they told the Emir Fadel of the coming of the Emir Abu Zeyd. And he rose up quickly and went forth and saluted him with the salute of peace and brought him to the Divan and gave him a seat at his side. And he sat him down in comfort. And Abu Zeyd brought forward his gifts, and he restored the mare to Fadel, and Fadel's heart was cured of its sickness. And they sent for all the princes, and they wrote the contract of the marriage of Alia, and the wedding was made between Alia and Abu Zeyd. And they made a seven days' rejoicing. And Abu Zeyd remained yet a long while with them, but at the last he grew weary and longed for his own people. And he asked leave of the Agheyli that he should depart, who straightway agreed, and gave to Alia all manner of convenience and gifts for the journey. And they arose and departed, he and she together, to those their lands. And they lived thus in happiness until the end of their time.

TO GOD BE PRAISE! 



\section{NOTES.}

Page I. The Emir Abu Zeyd the Helali Salame.-Salame Abu Zeyd, the hero of this as of the other romances of the cycle, was the eldest son of the Emir Risk, Sheykh of the Helalat, of Hejaz, in central Arabia. By an accident connected with his birth Salame was born black-faced and so was cast out of the tribe by his father. Later, however, by his deeds of valour, he proved his legitimacy and his right to his father's succession, and was recognized as their prince by the Helalat, whom he led to many victories. His darkness of face is in the romance a constant source of mystification, for, though a clear dark skin is not otherwise than a sign of pure blood with the Arabs, Abu Zeyd's colour would seem to have suggested negro affinities which the true Arabs resent and despise. Abu Zeyd is the family patronymic, Salame the personal appellation, Mukheymer a nickname.

"Beni Helal," literally the children of the Helal or Full Moon, a tribal name of Pre-Islamic origin, connected perhaps with ancient Totem worships (compare Professor Robertson Smith). All the more ancient tribes were called by the names of such Totems, as the "Sebaa" (of the lion), "Muteyr" (of the rain), "Anazeh" (of the goat). Helali is the form used for the individual, Helalat in the plural, Helal for the tribe generally. So, too, Agheyl, Agheyli, Agheylat. "Abul Komsan," literally "Father of Shirts," a nickname of one well clothed.

"There is the best of news for thee."-The best, because of the I 2 I R 
custom of hospitality which considered the guest a blessing sent by Heaven.

PAGE 3. "Built for ber a tent."--Such is the Arabic expression which uses the same verb for the setting up of a tent as of a house. The same noun too is used, the tent being distinguished as the "house of hair," the house as the " house of stone."

PAGE 4. "The dark one tbrew off bis cloak."-Abu Zeyd throws his cloak to his slave as showing his delight. This is a trait of openhandedness, indicating a hero, in modern as in ancient times. Abdul Kerim Jerba, the modern Hatim Taï, was nicknamed "Abu Khod" (literally Father of Take it) from his custom of giving to all comers.

"Sultan Hassan."-The title Sultan, though pure Arabic, is not used by the Bedouins or at all by the Arabs until the eleventh century of our era. It is one of the indications of the date of the poem.

"So God send ber to me."-This would seem to be a kind of competition between them as to the good fortune of entertaining the guest.

"The Lords of the Bedu."-The Bedu, i.e., the Bedouins. "Bedu" is the correct plural of "Bedawi," a wanderer, which Europeans have changed into Bedouin, Bedouins.

PAGE 5. "Fulano and Fulano."-So the Spaniards render the Arabic "Fulan," corresponding to our "Mr. So and So," or the French "Monsieur un tel."

PAGE 6. "Thou slave and idle talker."-She mistakes Abu Zeyd for a slave on account of his colour, nor does he at first correct her.

"All, to the cord, I give."-As of one who gives a camel and the cord with it.

PAGE 8. "We ask for bim Betina."-Naaman's act of refusing Betina to her cousin Amer is a breach of Bedouin law, which acknowledges a right in first cousins to the hands of marriageable girls. At the present day the consent of all first cousins on the father's side must be obtained to a girl's marriage with a stranger.

PAGE 10. "Colocynth of the desert."-Alkam, the bitter wild gourd of the desert.

"Clothed in the robes of amber."-The best of clothing, the more to ingratiate. 
PAGE I I. "Even of the sboulder-meat."-In serving a lamb to a guest the shoulder is the joint set nearest him."

PAGE I 2. "Lute."-The "rebab," or Bedouin fiddle, a square frame of wood covered with skin, and played, with a bow of hair plucked from the mare's tail, on a single string, a sweet melancholy accompaniment to all desert singing.

"O Mukbeymer."-One of the titles of Abu Zeyd.

PAGE 14. "And thus to the Divan."-The Diwan or assembly held in the Sheykh's tent every morning for tribal business.

"And the Sultan Hassan bearing struck bis two palms togetber."-A sign of grief.

PAGr I6. "The slaves of the Agbeylat."-Employed as herdsmen. Such may at the present day be found in Nejd, but domestic service is the more usual occupation of slaves and is held more honourable by them.

PAGE 17. "And fifteen days I journeyed, making of fifteen eight."Perhaps five hundred miles in the eight days.

"Tied ber fast by the fore leg." - The knee bound to the head by the halter to prevent her rising.

$P_{A G E}$ I 8. "Our stranger guest or a prowler."-A single camel rider would be a natural object of suspicion in the desert. A stranger is an enemy until he has accepted hospitality.

PAGE 20. "In this mare are there four qualities." - It is difficult to understand $A$ bu $Z$ eyd's meaning in this speech. But he doubtless intended it in a different sense from that given to it by the girl.

PAGE 22. "Mute girls wobo speak by signals."-Slaves, perhaps mutilated to insure their silence.

PAGe 25. "Not with the Persian kings, the Chosroës, the Irani."-The pre-Islamic Kings of Persia.

"In beight twice eight, sixteen."-Query sixteen hands?

PAGE 27. "Get thee gone from our dwellings."-She bids him begone, unwilling to betray her guest even should he prove a traitor. Women, if alone in the tent, will often entertain strangers, observing the same honourable law as in the case of men.

PAGE 29. "And lo, a spreading tree."-Probably a thorny acacia. Such are found here and there in the desert of considerable size and are superstitiously regarded. (Compare Mr. Doughty's "Arabia.") 
PAGE 30. "And be bad a mind for sbame's sake to slay them botb."Such an intrigue with an unmarried girl would be held disgraceful in Bedouin life as a fraud on the girl's father. Hence Abu Zeyd's anger. "Are ber eyes more fairly painted?"-The painting of the eyes with kohl is universal with Arab women and very common with Arab men.

$P_{A G E}$ 31. "And their bair was loosened from the plaits."-This would only be done in the closest privacy.

"I bave but this one desire, to avenge the blood of my fatber." - The blood vengeance is the motive of nearly half the Arab stories current at the present day. It represents the most sacred of all duties.

PAGE 33. "The space bath been stepped by the trackers." - In every tribe there are certain men specially skilled in tracking. These are the "kassasin." A tribe when on the march, and not in fear of attack, will be found spread over many miles, and there are seldom more than half a dozen tents within sight of each other.

PAGE 34. "Sabel seized bold of ber by the neck ornaments."-Not to rob her of them, but as one would seize a young camel by its neckrope.

PAGE 35. "Haass! Haass!"-Forbid, meaning "God forbid." Used in expostulation.

PAGE 42. "Do thou recite the Fatba."-The whole of this beautiful passage illustrates the Mohamedan view of a Moslem woman's position towards God. Alia prays to God in her need, but not according to the praying formulas of the men, which she had not learned. The "Fatha," which is the first chapter of the Koran, is the Moslem act of faith, and is repeated by the men on all solemn occasions, as for a dying man too weak himself to speak the words, or, as in the present instance, for one ignorant of them. Sahel's refusal to recite them for her is a great act of impiety. Alia none the less prays; and the passage will serve as a refutation of the foolish fancy of European writers, that Moslem women have no religion. They do not attend public prayers, and few of them say the prayers prescribed to the men, but this is only part of their general lack of education.

PAGE 43. "Calling on thee by the name of thy deeds."-The miracuI 24 
lous first victories of the Moslem Arabs, which are held by Mohamedans to be a proof of God's divine guidance of His true believers.

PAGE 44. "In some far dirra."-The word " dirra" is used for the district occupied by each tribe for its pasturing, and within which it remains except when at war.

"The wolf is not as the lion in the manner of its seizing."-This would seem to mean that the wolf (or possibly the jackal is here intended) does not wander far for its prey as the lion does. Abu Zeyd would be found nearer home.

PAGE 46. "Nor is there blood between us."-The Arabs never slay a captured enemy except in payment of a debt of blood.

PAGE 47. "Know, O lady, that I am of the race of the Finns. Our people are indeed of the Muslims."-Abu Zeyd pretends that he is an Afrit or Jinn because he fears Alia, there being "blood" between him and the Agheylat. The Jinns are accounted Moslems, that is true worshippers of the one God, though not men. Berkhán is their king, and Shemhurish and Tayar are of their princes.

"Stretch forth thy band that we may make a covenant togetber." This is the "Khuwa," or covenant of brotherhood, taken between men of different tribes, and precluding them from fighting against or injuring each other, even if there be "blood" between the tribes. It is interesting to find the oath taken here between a man and a woman. It is identical, doubtless, with the covenants recorded in several passages of the Old Testament.

PAGE 48. "And when Alia beard this word it deepened ber regard for bim." - That he was so modest a lover.

PAGE 49. "The Shobba," i.e., the grey.

PAGE 51. "In Sbam."-In Syria.

PAGE 52. "And I placed the veil between us, and we beld fast by the girdle."-The Arabian oath of brotherhood is taken, the two persons sitting on the ground. They grasp each other's girdle with the left hand, raising the right hand, and pronouncing the name of God. The meaning of the veil is not clear, and perhaps the better reading would be "and I set her veil aside."

PAGE 53. "Witb me are ber bobbles' keys."-All mares of value are kept hobbled with iron fetters in the desert to prevent theft. 
These are opened with a key turning a screw, and are not easily picked.

PAGE 58. "And she commanded that the drums sbould be beaten."Tobl, the drum, is an instrument, we believe, of Arab invention. From Arabia it passed to the Turks, and so into Europe. The Arab drum is of diminutive size.

PAGE 6o. "And she fetched a throne of gold inlaid with crusts of jewvels." - This is clearly a townsman's interpolation, as no form of chair is used in Arabia, nor furniture of any costly kind.

PAGE 6I. "This is a boly man, one unacquainted with women."-Celibacy, though contrary to true Mohamedan teaching, is looked upon in North Africa as an additional virtue in the case of professedly holy men. So are nearly all forms of asceticism. Throughout the present poem the religious and magical element represents the ideas of the North African Arabs rather than of the Arabs of Arabia proper.

PAGE 64. "And woben their meal was ended, they brought wine and drank of it."-In Arabia and all Mohamedan countries it is not the custom to drink during meals, but when the meal is ended. The allusion to wine-drinking is a town idea, as wine is quite unknown to the Bedouins.

PAGE 65. "And sbe clung to bis stirrup."-Again a town idea, as the true Bedouins do not ride with stirrups.

PAGE 69. "Yet leave the cords."-The meaning of this advice is obscure.

PAGE 70. "And I named the name of God, and I leaped into the saddle."-The Arabs on all journeys or adventures, or on mounting a horse for the first time, ejaculate, "Bismillah er rahman er rahim," "In the name of God the Merciful the Compassionate."

PAGE 74. "O thou of the race of Himyar."-The Beni Helal claimed descent from Himyar, the progenitor of the Himyarite kings of Yemen.

PAGE 76. "And about the bour of the Doba."-The Doha is the point of time half-way between sunrise and noon, or a little earlier ; as the Asr is half-way between noon and sunset.

PAGE 79. "And be called on those near bim ... to bring zoood and I 26 
ligbted coals to burn ber witbal."-This condemning of Alia to be burnt, and her rescue by Abu Zeyd, compares closely with mediæval practice in Europe, as when Guinevere is condemned to be burnt by King Arthur and is rescued by Launcelot in Mallory's version of the "Morte d'Arthur."

PAGE 88. "We will make thee a fair sepulcbre."-Holy men among the North African Arabs are commonly buried in conspicuous whited sepulchres, and yearly festivals, "mowlids," are held at them, when sheep and camels are sacrificed and their intercession is invoked.

PAGE 89. "Burn not, O noble fire."-He bears witness against the fire as a descendant of the Prophet.

PAGE 90. " $A$ wely," i.e., a saint.

PAGE 92. "Bedr ibn Saleb er Ramal."-The sand-diviner. Omens in Arabia are often asked on doubtful occasions by means of lines marked on the sand, and crossed out according to certain rules of calculation. Men skilled in this science are called "Ramál," from the root "raml," sand. All such divination is, however, forbidden by the law of the Koran, as witchcraft was forbidden to the Jews. Bedr ibn Saleh seems, however, to have been more than a "ramal," and his work is that of a true magician, such as are still to be found in Morocco, and perhaps in Egypt.

$\mathrm{P}_{\mathrm{AGE}}$ 100. "As it were in bandfuls of cotton."-An Egyptian simile.

PAGE 106. "Even by the Valley of Barbut."-Barhut, or Barahut, a valley of Hadramant, the abode of infidels after death.

PAGE 107. "A Mogrebbin."-From the Mogreb, the West, i.e., Marocco.

PAGE I I3. "Lead forth the mare, the Hamameb."-The Hamameh, the dove, a name often given to mares or she-camels.

PAGE II 4. "Thou bast done us a service, for tbis one refnsed to do according to our counsels." - The Sheykh of an Arabian tribe or town is no absolute ruler. He governs by the advice of a Council of Elders, who limit his authority. 


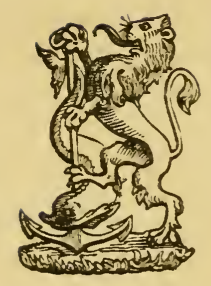

CHISWICK PRESS :-C. WHITTINGHAM AND CO., TOOKS COURT, CHANCERY LANE. 

Welostar Family a y of Veternary bledicube Cimmings Scho "Y Verorinary Medicines?

$$
\text { Tufts University }
$$
200 Westboro Road worth Gration MA OAS 
